\title{
Új kismolekula-alapú módszerek kidolgozása és alkalmazása
}

\author{
Ph.D. értekezés
}

\section{Molnár Eszter}

Témavezető: Dr. Puskás László

Biológia Doktori Iskola, SZTE-TTIK

MTA SZBK, Funkcionális Genomika Laboratórium

2013.

Szeged 


\section{Tartalomjegyzék}

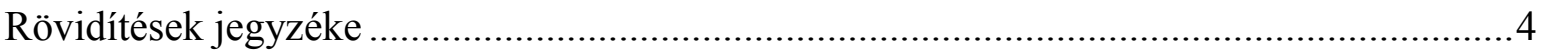

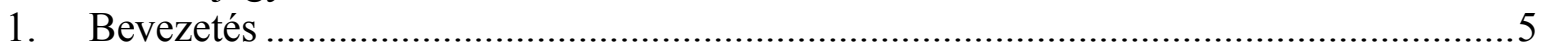

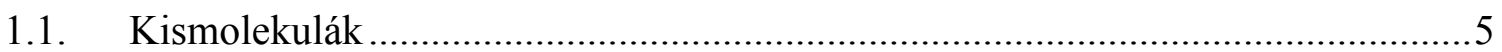

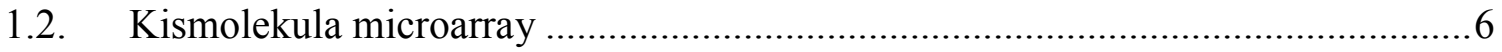

1.3. Fluoreszcens jelölés és képalkotás ............................................................. 8

1.3.1. Fluoreszcens fehérjék és kismolekula festékek ............................................ 10

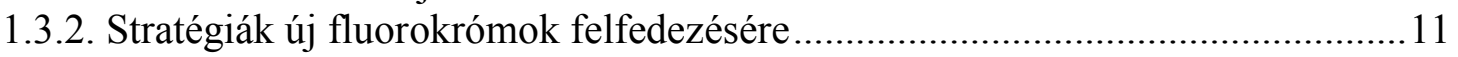

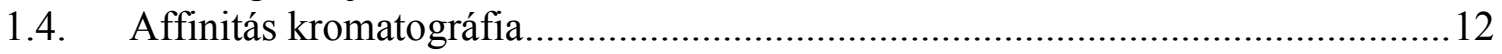

1.4.1. Célpontazonosítás affinitás kromatográfiával .............................................. 12

1.4.2. Az affinitás kromatográfia hatékonyságának növelése a nem-specifikus fehérjék

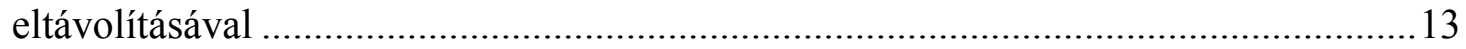

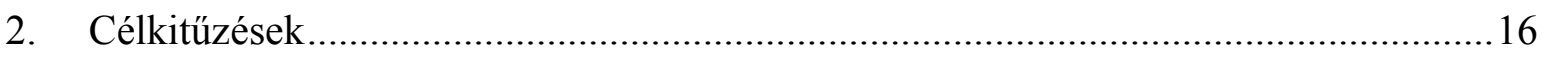

2.1. Kismolekula microarray és konfokális pásztázó mikroszkópia együttes alkalmazása élő sejteket festő fluoreszcens markerek azonosítására ............................. 16

2.2. Speciális felülethez kapcsolt kismolekulák alkalmazása affinitás kromatográfiában

2.2.1. AviLink felületmódosítással ellátott affinitás töltet előállítása és felhasználása célpontazonosításban ............................................................................ 16 2.2.2. Nem-specifikusan kötődő fehérjék eltávolítása sejt- és szövetkivonatokból 2aminobenzimidazollal kapcsolt affinitás töltettel ............................................... 17

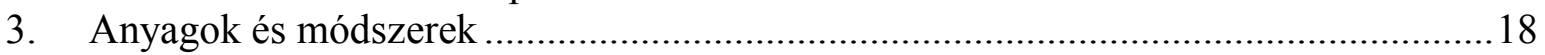

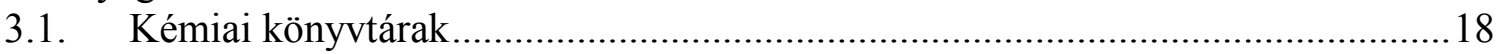

3.2. Kismolekula microarray-ek előállítása .......................................................... 18

3.3. A fluoreszcencia intenzitások mérése és kiértékelése ....................................19

3.4. Sejtkultúra kezelések ............................................................................. 19

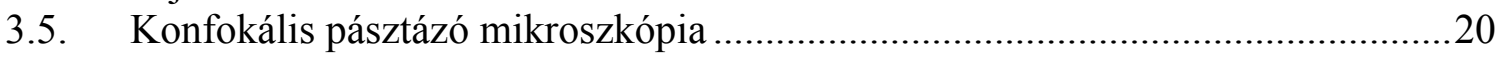

3.6. Teljes fehérjekivonat előállítása patkány májból..........................................20

3.7. Ac-2010-zel kapcsolt affinitás töltet előállítása.............................................21

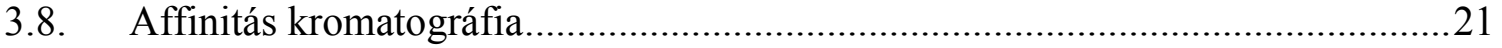

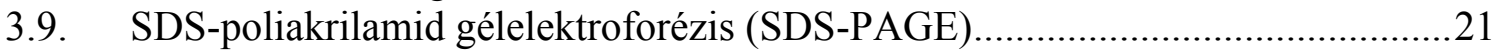

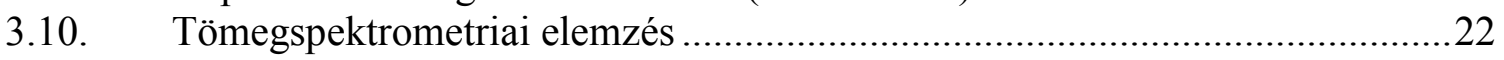

3.11. Protein diszulfid izomeráz (PDI) enzimaktivitás mérése inzulin-

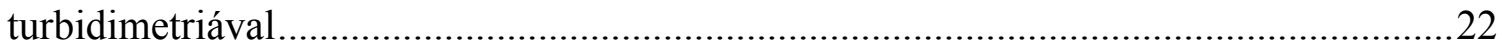

3.12. 2-aminobenzimidazollal kapcsolt affinitás töltet elöállítása.........................23

3.13. A széntartalom meghatározása és a felületi lefedettség kiszámítása ................23

3.14. Teljes fehérjekivonat elöállítása állati szövetből és humán sejtkultúrából

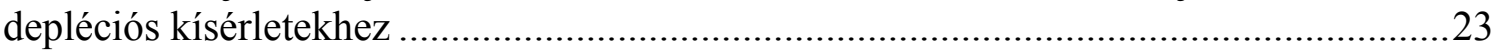

3.15. Nem-specifikusan kötődő fehérjék depléciója 2-aminobenzimidazol töltettel.24

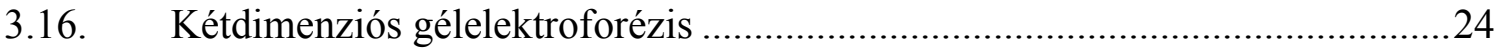

4. Eredmények és diszkusszió .....................................................................26

4.1. Kismolekula microarray és konfokális pásztázó mikroszkópia együttes alkalmazása élő sejteket festő fluoreszcens markerek azonosítására ..............................26

4.2. Speciális felülethez kapcsolt kismolekulák alkalmazása affinitás kromatográfiában 
4.2.1. AviLink felületmódosítással ellátott affinitás töltet elỏállitása és felhasználása

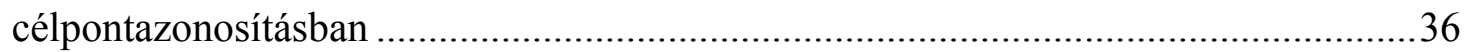

4.2.2. Nem-specifikusan kötődő fehérjék eltávolítása sejt- és szövetkivonatokból 2aminobenzimidazollal kapcsolt affinitás töltettel .......................................................40

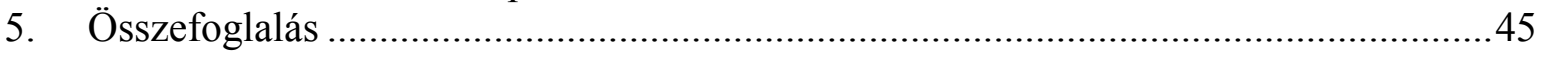

5.1. Kismolekula microarray és konfokális pásztázó mikroszkópia együttes alkalmazása élő sejteket festő fluoreszcens markerek azonosítására ..................................45

5.2. Speciális felülethez kapcsolt kismolekulák alkalmazása affinitás kromatográfiában

5.2.1. AviLink felületmódosítással ellátott affinitás töltet előállitása és felhasználása célpontazonosításban

5.2.2. Nem-specifikusan kötődő fehérjék eltávolítása sejt- és szövetkivonatokból 2aminobenzimidazollal kapcsolt affinitás töltettel .......................................................4 48

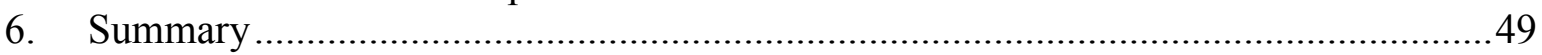

6.1. Combination of small molecule microarray and confocal microscopy techniques for live cell staining fluorescent dye discovery ...............................................................49 6.2. Affinity chromatographic application of small molecules immobilized on specific surfaces

6.2.1. Preparation and use in target identification of an affinity matrix based on AviLink surface modification technology

6.2.2. Removal of nonspecific binding proteins from cell and tissue extracts using 2aminobenzimidazole-tethered affinity resin

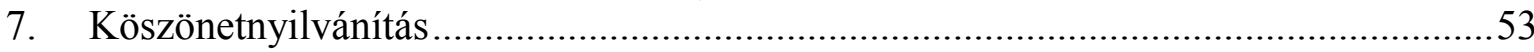

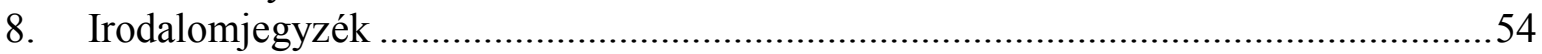

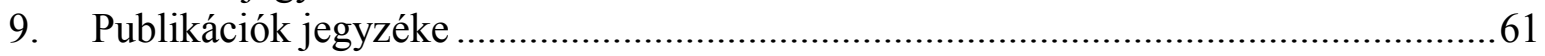




\section{Rövidítések jegyzéke}

C2*: fotokonvertált C2 vegyület

CPG: kontrollált pórusú üveg (controlled pore glass)

DAPI: 4',6-diamidino-2-fenilindol

DMEM: Dulbecco által módosított Eagle-féle médium (Dulbecco's Modified Eagle Medium)

DMSO: dimetil-szulfoxid

DTT: ditiotreitol

EDTA: etiléndiamin-tetraecetsav

EGTA: etilénglikol-tetraecetsav

ER: endoplazmatikus retikulum

FDA: fluoreszcein diacetát

GFP: zöld fluoreszcens fehérje (green fluorescent protein)

H33342: Hoechst 33342

HT: 4-hidroxitamoxifen

HTS: nagy áteresztöképességü szürés (high-throughput screening)

IPG: immobilizált pH-grádiens

LC-MS/MS: folyadék kromatográfia-tandem tömegspektrometria (liquid chromatographytandem mass spectrometry)

MALDI-TOF MS: mátrixszal segített lézer deszorpciós ionizáció repülésidő tömegspektrometria (matrix-assisted laser desorption/ionization time-of-flight mass spectrometry)

NAO: nonil-akridin-narancs (nonyl acridine orange)

PAGE: poliakrilamid gélelektroforézis

PBS: foszfát-pufferelt sóoldat (phosphate buffered saline)

PDI: protein diszulfid izomeráz

SDS: nátrium-dodecil-szulfát

UV: ultraibolya 


\section{Bevezetés}

A néhány száz Dalton tömegủ szerves vegyületek, más néven kismolekulák amellett, hogy az élő sejtek alapvető alkotóelemei közé tartoznak - a gyakorlatban elsősorban gyógyszerekként és a molekuláris biológia eszközeiként ismertek. A dolgozat olyan kismolekulákon alapuló módszertani fejlesztéseket mutat be, mint a kismolekula microarray és konfokális pásztázó mikroszkópia kombinálása új fluoreszcens festékek azonosításában, illetve a speciális felülethez kapcsolt kismolekulák alkalmazásai affinitás kromatográfiában.

\subsection{Kismolekulák}

A kismolekulák olyan alacsony molekulatömegü ( $<900 \mathrm{Da})$ szerves vegyületek, amelyek számos biológiai funkcióval rendelkezhetnek: lehetnek jelmolekulák vagy építőelemek (pl. aminosavak, nukleotidok, cukrok) a sejtekben, eszközök a molekuláris biológiai kutatásokban, szolgálhatnak gyógyszerként vagy növényvédőszerként, és még folytathatnánk a sort.

A farmakológiában az elnevezést általában olyan molekulákra korlátozzák, amelyek valamilyen biopolimerhez (mint a fehérjék, a nukleinsavak vagy a poliszacharidok) kötnek és megváltoztatják az adott biopolimer aktivitását vagy funkcióját, molekulatömegük felső határát pedig - a Lipinski-féle ötös szabály alapján [1] - egy kisebb értéknél (500 Da) húzzák meg.

A modern technológiák folyamatosan nagyszámú új kismolekula szintézisét igénylik, így századunkban a kémia egyik legfontosabb problémájává vált, hogy hogyan lehet minél több vegyületet minél kevesebb idő alatt előállítani. A megoldást a kombinatorikus kémia kidolgozása jelentette [2]. A kombinatorikus kémia robotizált és manuális eljárásokat használ nagyszámú, kis léptékü kémiai reakció elvégzésére, amelyek mindegyike másféle reagenskombinációt alkalmaz szimultán vagy párhuzamos módon, így rövid idő alatt nagyszámú diverz szerkezetủ molekulát vagy molekulahalmazt eredményez. Az eljárással előállított vegyületek gyüjteményét nevezzük kémiai könyvtárnak [3]. 


\subsection{Kismolekula microarray}

A microarray technológia két évtizeddel ezelőtti megjelenésével új távlatok nyíltak a molekuláris biológiai kutatásokban: biomolekulák közti kölcsönhatások tízezreinek detektálása vált lehetővé egyetlen tárgylemeznyi felületen.

A DNS- és fehérje microarray-ek után kifejlesztett kismolekula microarray-ek elegánsan ötvözik a kombinatorikus kémia nyújtotta lehetőségeket a microarray technika szürési kapacitásával [4-6]. Előállításuk során nagyszámú kismolekulából álló könyvtárat kapcsolnak szilárd felülethez, amelyet azután ebben a formában hoznak érintkezésbe a lehetséges kötőpartnerrel (általában egy fehérjével). Szilárd felületként legtöbbször szilikát (szilícium-dioxidot) vagy üveget alkalmaznak olyan tulajdonságaik miatt, mint az oldószerekkel szembeni kémiai ellenállóképesség, a nagy mechanikai stabilitás, az alacsony háttérfluoreszcencia és a könnyen kialakítható funkciós csoportok [7].

A kismolekulák rögzítése történhet in situ szintézissel, illetve kovalens vagy nemkovalens kölcsönhatás révén. A kovalens kötés kialakításához szükség van megfelelö funkciós csoportok (általában amin, karboxil vagy aldehid) jelenlétére a kismolekulán. Ehhez gyakran elő kell állítani a molekula alkalmas analógját és egy linkert is be kell iktatni a molekula és az aktivált felület közé, amely biztosítja a fehérjék számára a molekulához való hozzáférést. Ez az eljárás megváltoztathatja a molekula biológiai aktivitásáért felelős szerkezeti részletét, ráadásul az sem biztos, hogy az immobilizált ligandnak ugyanazok lesznek a fehérjekötő tulajdonságai (specificitása és/vagy affinitása), mint az eredeti molekulának, így lehet, hogy a fehérje ki sem kötődik hozzá. Ezek a problémák nagyrészt kiküszöbölhetők az általunk kifejlesztett AviLink felülettel [4, 6], amely több lépéses kémiai reakciók során létrehozott elágazó láncú, fa-szerủ struktúrákat hordoz, ahol az „ágak”végén különböző aktivált funkciós csoportok találhatók (1. ábra). Az elágazások növelik a felület kapacitását (nagyobb mennyiségü minta köthető ki), illetve megfelelö távolságot képeznek a felvitt molekula és az üveg felülete között. A többféle funkciós csoport pedig univerzális kihorgonyzó helyet biztosít szinte bármilyen kismolekula számára, feleslegessé téve ezzel a megfelelő származék legyártását. További előny, hogy ugyanaz a kismolekula különböző csoportjainál fogva kötődhet ki, ezáltal megnövelve az esélyét annak, hogy aktív része a fehérjék számára hozzáférhető marad. 


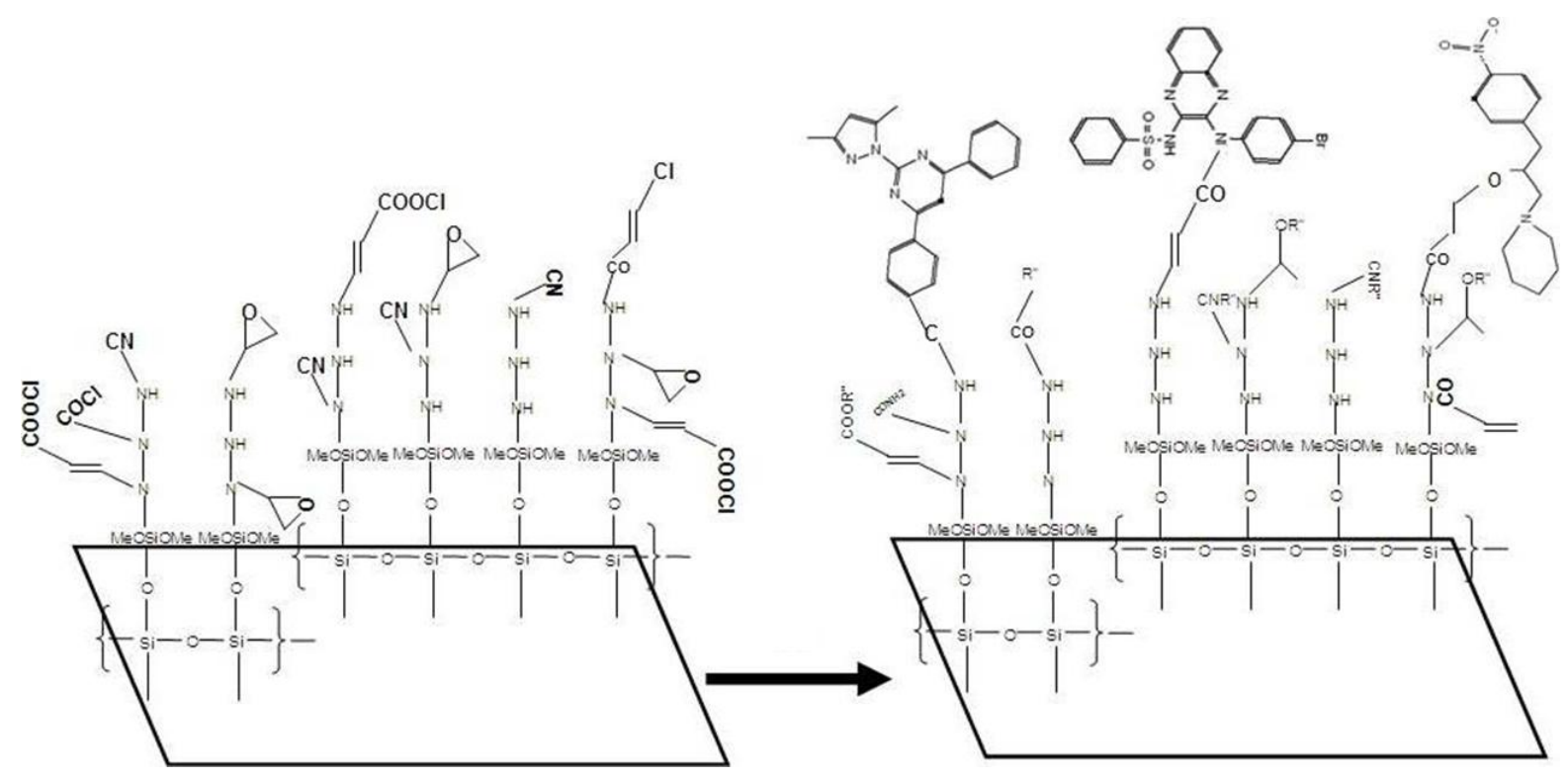

1. ábra. Kismolekulák kikötődése az AviLink felülethez. Az elágazások végein található különböző funkciós csoportok univerzális kihorgonyzóhelyet biztosítanak szinte bármilyen kismolekula számára.

A DNS microarray-ekhez hasonlóan a kismolekulákat is robotnyomtatóval viszik fel az aktivált felületre. A vegyületek rögzítését követően a microarray-t a vizsgálni kívánt fehérje oldatával inkubálják. Az inkubáció alatt a fehérje és bizonyos (specifikus) kismolekulák között kölcsönhatás jön létre, amelyet a fehérje előzetes kolorimetriás, fluoreszcens vagy lumineszcens jelölésével tesznek láthatóvá [7]. A nem-kötődött fehérje lemosása után a microarray-t (pl. lézerszkennerrel) beolvassák, majd a kapott képet szoftveres elemzésnek vetik alá, hogy megállapítsák a fehérjével kölcsönható kismolekulák helyét és identitását (2. ábra). 

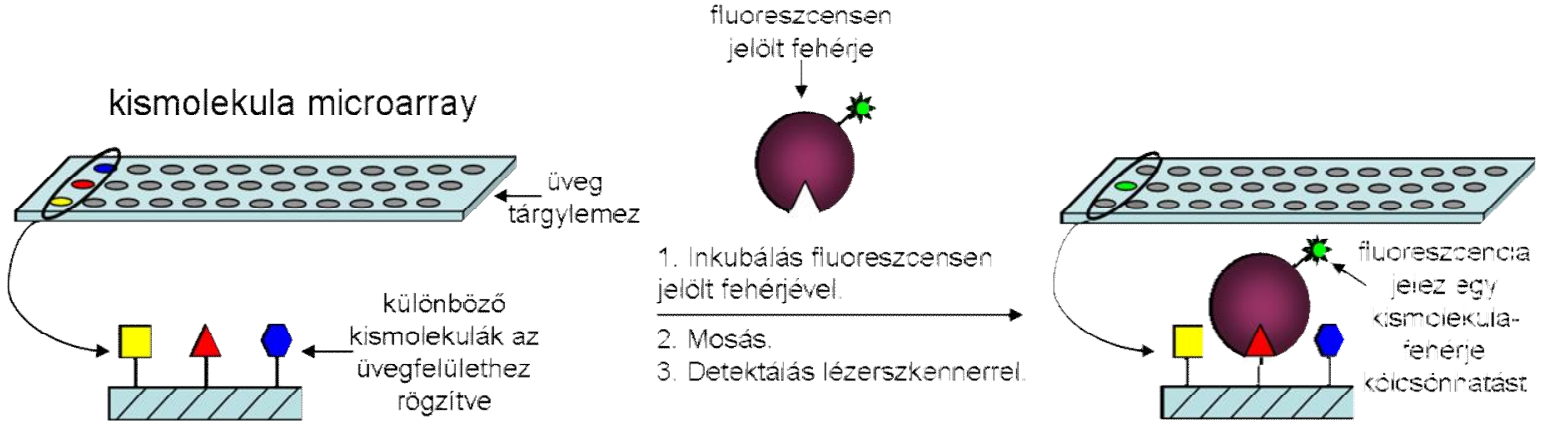

2. ábra. Egy tipikus kismolekula microarray kísérlet vázlatos rajza. Az üveg tárgylemezen rögzített kismolekulák közül egyesekhez kötődik a fluoreszcensen jelölt fehérjeminta. A detektált fluoreszcens jel mutatja a kölcsönható kismolekula helyét.

A kismolekula microarray-eket sok esetben alkalmazták már különböző enzimekkel [8-11], transzkripciós faktorokkal [12] vagy extracelluláris növekedési faktorokkal [13] specifikusan kölcsönható kismolekulák azonosításában. Ha a vizsgálat tárgya valamilyen betegség kialakulásában jelentős szerepet betöltő fehérje (más néven target vagy célpont), akkor azok a molekulák (azaz hitek), amelyek az adott célponttal in vivo kölcsönhatva módosítják annak aktivitását vagy funkcióját, gyógyszerré fejleszthetők.

Bár csoportunk az Avicor Kft.-vel együttmüködésben több gyógyszerkutatási projektben is sikerrel használta fel ezt a technológiát, a dolgozatban a kismolekula microarray-ek egy másik alkalmazási területét fogom bemutatni: az új fluoreszcens festékek felfedezését.

\subsection{Fluoreszcens jelölés és képalkotás}

Bizonyos anyagok az elnyelt fény- vagy más elektromágneses sugárzás hatására fényt bocsátanak ki. Ez a jelenség a lumineszcencia. A lumineszcencia azon esetét, amikor a gerjesztő hatás megszünte után a fénykibocsátás csak igen rövid $\left(<10^{-6} \mathrm{~s}\right)$ ideig folytatódik, fluoreszcenciának nevezzük. A világítástechnikától az ásványtanon és a szerves anyagok analízisén át az élettudományokig számos terület él a fluoreszcencia nyújtotta lehetőségekkel.

A biológiában a fluoreszcens jelölést széles körben alkalmazzák olyan kérdések megválaszolására, amelyek a sejt specifikus biomolekuláinak jelenlétével, lokalizációjával, 
funkciójával, szabályozásával és kölcsönhatásaival kapcsolatosak. Alkalmazási területei között találjuk az immunhiszto- és citokémiát, a sejtkövetést, a ligand-receptor kötési vizsgálatokat és a fluoreszcens in situ hibridizációt.

Az első fluoreszcens kismolekulát, a kinin-szulfátot, Sir John Herschel írta le 1845ben [14], bár szigorúan véve ez így nem teljesen igaz, mivel a „fluoreszcencia” szó 1852-ig nem is létezett, amikor is George Stokes publikált egy cikket a témában [15]. A kinin-szulfát felfedezése óta, amely ultraibolya (UV) fénnyel megvilágítva kéken fluoreszkál, sok más, különböző hullámhosszakon emittáló szerves molekulát fedeztek fel vagy állítottak elő. Tipikus példák a fluoreszcein [16] és a rodamin [17] származékai, amelyeket először a 19. század végén írtak le. A BODIPY [18] és a cianin festékeket [19] szintén gyakran használják a képalkotó eljárásokban.

Néhány évtizeddel az első fluoreszkáló szerves molekulák kifejlesztése után feltalálták és biológiai kutatásokban alkalmazták a fluoreszcens mikroszkópiát. A fluoreszcens mikroszkópot - mint Köhler UV-mikroszkópjának utódját - Reichert és Heimstädt írta le 1911-ben és Lehmann 1913-ban [20]. Az első tanulmányozott minták között voltak növények, baktériumok és állati szövetek, amelyek spontán fluoreszcenciájuk miatt szolgáltak megfelelő alanyként a fluoreszcens mikroszkópos vizsgálatokhoz. 1914-ben von Prowazek megtette az első kísérleteket sejtek fluoreszcens festésére [21]. Egy másik fontos fejlesztés 1942-ben történt, amikor Coons fluoreszcein-izocianáttal kovalensen jelölt antitesteket és fluoreszcens mikroszkópos képalkotásban alkalmazta azokat [22]. Ez volt a mai napig széles körben használt immunfluoreszcencia kezdete. Az első természetes fluoreszcens fehérjét Shimomura izolálta az Aequorea victoria nevü medúzából 1962-ben [23], de az úgynevezett zöld fluoreszcens fehérje (GFP) molekuláris biológiai eszközként való felhasználása egészen a 90-es évekig váratott magára [24-26].

Napjainkra számos fluoreszcens jelölö ágenst fejlesztettek ki, köztük olyan vegyületeket, amelyek szelektíven festenek egy-egy sejtorganellumot, mint például a mitokondriumokat, a lizoszómákat, az endoplazmatikus retikulumot (ER) vagy a Golgiapparátust. A leggyakrabban alkalmazott fluoreszcens próbák talán a nukleáris festékek, mint a 4',6-diamidino-2-phenylindole (DAPI) [27] és a Hoechst 33258 [28], amelyek erősen fluoreszkálnak, ha DNS-hez kötnek. 


\subsubsection{Fluoreszcens fehérjék és kismolekula festékek}

A fluoreszcens képalkotó eljárások során leggyakrabban fluoreszcens fehérjéket és kismolekula festékeket (más néven fluorokrómokat) alkalmaznak a sejt alkotórészeinek jelzéseként. Mind az alap- mind az alkalmazott kutatás - beleértve a klinikai diagnosztikát is - profitál ezeknek az eszközöknek a felfedezéséböl [29, 30].

Ha rendelkezésünkre áll egy marker - vagyis egy olyan fehérje, amelynek expressziója jellemző egy bizonyos kompartmentre, állapotra vagy sejttípusra -, könnyen

készíthető ellene jelölt antitest vagy előállítható a fluoreszcens fehérjével kapcsolt formája ennek a markernek. Azonban a sejtek fixálásának és permeabilizálásának szükségessége miatt az előbbi módszer nem ad információt a sejtes rendszerek dinamikájáról. Ezzel szemben az olyan fehérjék, mint a GFP és társai lehetővé teszik más fehérjék követésének statikus és dinamikus módját egyaránt, mivel a vizsgált gén termékével alkotott fúziós fehérjeként működnek [31, 32]. A fluoreszcens fehérjék új, mutagenezissel előállított formái [33] széles körben használt eszközökké váltak köszönhetően a megnövekedett stabilitásnak, fényességnek és a széles spektrális tartománynak. Emellett lehetővé teszik a fehérjék valós idejű követését, a sejtes folyamatok dinamikájának elemzését és a biomolekulák kölcsönhatásainak igazolását olyan módszerek révén, mint például a Förster típusú rezonancia-energiatranszfer [34]. Azonban vannak hátrányaik is: jelenlétük és méretük miatt interferálhatnak a jelölt fehérje funkciójával és így - a fúziós fehérje ektopikus expressziójával együtt - megnehezítik a sejt természetes állapotának megjelenítését [35].

A GFP fúziós fehérjeként való alkalmazása előtt a kismolekulák nyújtották az egyetlen lehetőséget a fluoreszcens jelölésre. Azonban a fluoreszcens fehérjék széles körben való elterjedése sem tette feleslegessé a kismolekula festékeket köszönhetően az olyan tulajdonságoknak, mint a nagy membránpermeabilitás, az alacsony toxicitás, a minimális technikai korlátok és a viszonylag alacsony költségek. Habár napjainkban már több száz kereskedelmi forgalomban lévő fluorokróm létezik, továbbra is van igény az új célpontokat jelölő vagy továbbfejlesztett spektrális tulajdonságokkal rendelkező új molekulák iránt. 


\subsubsection{Stratégiák új fluorokrómok felfedezésére}

Több fluoreszcens festéket szerencsés véletlennek köszönhetően fedeztek fel: például a Nílus-vöröset akkor, amikor nyomokban jelen volt egy Nílus-kékkel készült preparátumban, és váratlanul megfestette a lipideket [36]. Újabban a racionális tervezési és a nagy áteresztőképességủ szürési (HTS) technikák jelentik az új fluorokrómok két fő forrását. A racionális tervezés során a célpont háromdimenziós szerkezetének birtokában tervezik meg/módosítják a kiindulási kismolekulát. Ez a megközelítés nagyon sikeresnek bizonyult a festékek fluoreszcens tulajdonságainak és célpontspecificitásának fejlesztésében [37], és új próbákat is eredményezett [38-41]. Azonban egy bizonyos célra (pl. egy fehérjemarker jelölésére) festéket gyártani időigényes és költséges folyamat, amely nagy számítási kapacitást, szaktudást és gyakran bonyolult kémiai szintézist igényel [42].

A HTS módszerek „aki keres, talál” alapon nagyszámú vegyület rövid idő alatt kivitelezhető szürésével operálnak, így előzetes szerkezeti ismeretek hiányában is alkalmazhatók. Ezáltal egy viszonylag olcsó és gyors alternatívát kínálnak új fluoreszcens próbák azonosítására: automatizálhatóvá teszik nagyszámú vegyület egyidejü tesztelését mindössze néhány mikroliteres térfogatban [43]. Míg ezeket a technikákat már széles körben használják a gyógyszerkutatásban, addig az új fluoreszcens festékek felfedezésében még kevéssé alkalmazták őket [44-48].

Korábban már esett szó a HTS módszerek közé tartozó kismolekula microarray-ről, amelyet elsősorban gyógyszerjelölt vegyületek azonosítására használnak. A kismolekula microarray elöállítása során a fluoreszcens molekulákat célszerủ mellőzni a vizsgálatokból, vagy a kapott adatok analízise során el kell tekinteni az ezekből származó jelektől, hiszen azok interferálhatnak a vizsgált fehérjeminta jelölésével. Így az erős natív fluoreszcenciát mutató vegyületek kiesnek ugyan a potenciális gyógyszermolekulák köréböl, de új fluoreszcens próbákat fedezhetünk fel köztük. Meg kell jegyeznünk azonban, hogy a szelektált vegyületek in vivo körülmények közötti alkalmazhatóságát nem garantálja ez a technika.

A sejtbiológia egyik általánosan használt eszköze, a konfokális pásztázó mikroszkópia révén nagy pontossággal vizsgálhatjuk az élő sejtek, organellumok és akár egyedi molekulák mobilitását, dinamikáját, kölcsönhatásait és elhelyezkedését [49]. Ezt 
olyan tulajdonságok teszik lehetővé, mint a nagy felbontás, a nagy érzékenység és az optikai szeletelés képessége. A mikroszkópos képek időigényes manuális analízise miatt azonban a hagyományos mikroszkópos technikák alkalmatlanok voltak nagyszámú minta gyors vizsgálatára egészen a nagy kapacitású (angolul high-content) mikroszkópos rendszerek megjelenéséig [50]. Ennek a technikának is akadnak viszont hátrányai, mint az automatizált képanalízis során jelentkező nehézségek vagy a magasabb költségek.

A két technológia, vagyis a kismolekula microarray és a konfokális pásztázó mikroszkópia kombinálásával lehetőségünk nyílik arra, hogy új fluoreszcens festékeket fedezzünk fel akár több tízezer molekula között. Első lépésként kismolekula microarray-ek segítségével kiszürhetjük az erősen fluoreszkáló vegyületeket, majd ezeket a kiválasztott molekulákat élő sejteken vizsgálhatjuk tovább konfokális pásztázó mikroszkóppal.

\subsection{Affinitás kromatográfia}

\subsubsection{Célpontazonosítás affinitás kromatográfiával}

A gyógyszerkutatás egyik fontos lépése annak a fehérjecélpontnak az azonosítása, amelyen keresztül a gyógyszerjelölt molekula a hatását kifejti. Ugyanakkor a kismolekula és más fehérjék közti kölcsönhatás nem kívánt mellékhatásokhoz vezethet. Affinitás kromatográfiával mindezen fehérjék meghatározhatók: a hordozóra rögzített gyógyszerjelölt molekula „kiválogatja” egy keverékből a hozzá kötődő fehérjéket, miközben a keverék a hordozón (oszlopon) átfolyik [51]. Ezzel a módszerrel Schreiber és munkatársai azonosítottak egy, az FK506 makrolid antibiotikumhoz kötődő peptidil-prolil cisz-transz izomerázt [52], illetve a trapoxinhoz kötődő hiszton deacetilázt [53], míg Fukuda és kollégái a leptomycin B lehetséges célpontjaként a CRM1 fehérjét határozták meg [54].

Ahogy a kismolekula microarray-ek esetében, úgy az affinitás kromatográfiás kísérletekben is gondot jelent, hogy szükség lehet a vizsgált kismolekula megfelelö származékának szintézisére, illetve hogy a molekula egyféle orientációban kötődik ki. Így elöfordulhat, hogy az adott ligand nem is tudná kikötni a célpontfehérjét. Ezekre a problémákra megoldást jelenthet az AviLink felületmódosítással ellátott kontrollált pórusú üveg (CPG) alkalmazása. Az így kezelt CPG-n jelenlévő többféle funkciós csoport egyrészt feleslegessé teheti a megfelelő származék előállítását, másrészt a kismolekula többféle 
helyzetben is kikötődhet, így megnő a valószínűsége annak, hogy aktív része a fehérjék számára hozzáférhető marad.

\subsubsection{Az affinitás kromatográfia hatékonyságának növelése a nem-specifikus fehérjék eltávolításával}

Összetett biológiai mintákban a valódi célpontfehérjék affinitás kromatográfiával történő azonosítását különösen megnehezíti az a jelenség, hogy a nagy mennyiségben jelenlévő fehérjék nem-specifikusan kötődnek a kismolekulát hordozó töltethez.

Változatos módszerek születtek a probléma megoldására. Egy általánosan alkalmazott eljárás a specifikus fehérjék szabad ligand feleslegével történő kompetitív elúciója az affinitás oszlopról (3. ábra). Ennek során a keresett célfehérjét úgy választják el a többi, nem-specifikus módon kikötődött fehérjétől, hogy a célfehérje ligandját tartalmazó oldatot engednek át az oszlopon. Ez a szabad ligand verseng az immobilizált társaival a fehérjéért, és mivel feleslegben van az utóbbiakhoz képest, ezért a specifikus fehérjemolekula eluálódik az oszlopról. 


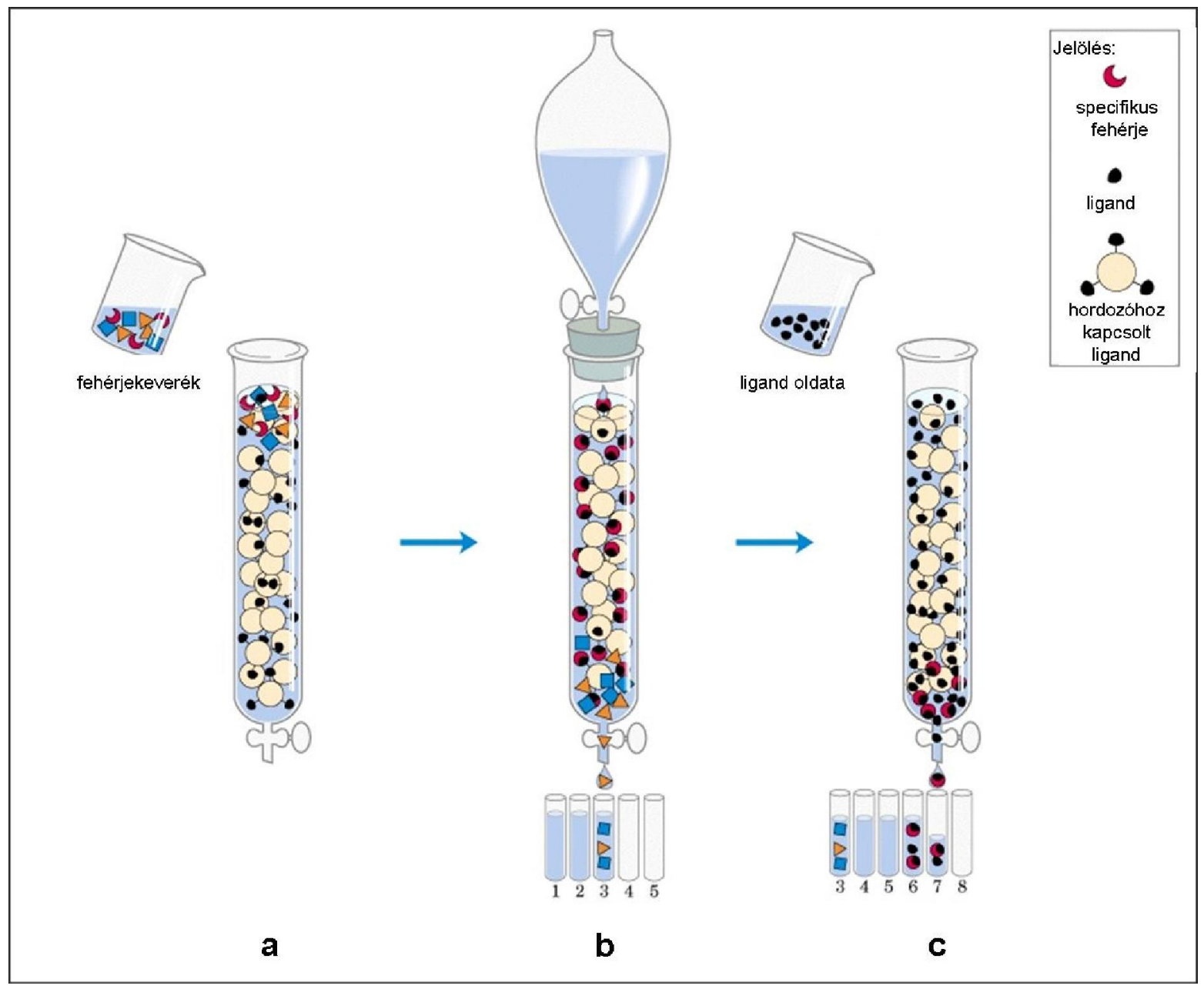

3. ábra. Kompetitív elúció. Fehérjekeveréket viszünk fel a ligandot hordozó oszlopra (a), majd lemossuk a gyengén kötődő fehérjéket (b), és a ligand oldatával eluáljuk a specifikus fehérjé(ke)t (c). (Az ábra a http://www.biochem.arizona.edu weboldal egyik illusztrációja alapján készült.)

Egy másik módszer során úgy határozzák meg a specifikus fehérjéket, hogy egy aktív és egy inaktív ligandot tartalmazó tölteten is átengednek ugyanolyan fehérjekeveréket, majd a kétféle töltethez kötődő fehérjéket hasonlítják össze, és csak azokat a fehérjéket tekintik specifikusnak, amelyek az aktív ligandhoz kötődtek, de az inaktívhoz nem [55].

A sorozatos affinitás kromatográfia módszere során egy fehérjekeveréket egymás után két ugyanolyan affinitás tölteten engednek át, majd az egyes töltetekhez kötődő fehérjéket hasonlítják össze. A specifikus fehérjéknek nagy affinitása van a tölteten immobilizált molekulához, ezért nagyobb részt az első töltethez kötődnek, míg a nem- 
specifikus fehérjék kis affinitásuk miatt hasonló mennyiségben kötődnek mindkét töltethez [56].

A felület [57, 58] és molekuláris távtartó kar [59] optimalizáló módszerek további lehetőségeket nyújtanak a nem-specifikusan kötődő fehérjék és a szilárd hordozó közti kölcsönhatások csökkentésére.

Egy másik - elsősorban plazma proteomikai tanulmányokból ismert - megoldás az abundáns fehérjék előzetes eltávolítása az analizált mintából dúsítási vagy depléciós módszerek révén. A ProteoMiner (Bio-Rad, USA) dúsítási technológia [60] azon alapul, hogy egy kromatográfiás töltetre nagy és változatos hexapeptid könyvtárat kötnek. Ezen engedik át a komplex mintát, majd a kifogott fehérjéket az oszlopról eluálják. Mivel az egyes fehérjék azonos mértékben kötődnek ki, a kezdetben fennálló nagy mennyiségi különbségek kiegyenlítődnek. Hátránya, hogy a fehérjék elúciójához szükséges magas sókoncentráció illetve alacsony pH korlátokat szab az ily módon kezelt minta további vizsgálatának: olyan analízisek előtt, ahol szükséges, hogy a fehérjék natív konformációs állapotban legyenek (pl. enzimmüködésen alapuló szürések vagy affinitás kromatográfia), nem alkalmazható.

Az immunaffinitáson alapuló depléciós oszlopok specifikus antitestekkel borított gyöngyökböl állnak, amelyek a nagy mennyiségben jelenlévő, az analízist zavaró szérumfehérjéket fogják ki [61, 62], és intakt, natív konformációval rendelkező fehérjéket eredményeznek az átfolyóban. Az ilyen elven müködő depléciós oszlopok alkalmasak lehetnek az ismert nem-specifikusan kötődő fehérjék eltávolítására affinitás kromatográfia előtt is, és antitestek helyett akár specifikus kismolekulák is használhatók ligandként.

A nagy mennyiségben jelenlévő citoszkeletális fehérjék, mint a tubulin és az aktin sokszor megnehezítik a gyógyszercélpontok meghatározását, mivel ezek sok affinitás oszlopon nem-specifikus módon kikötődnek. Kimutatták, hogy a benzimidazol kötődik a tubulinhoz fonálférgekben [63] és az emlös agyban [64], így egy benzimidazollal-kapcsolt affinitás töltet használható lehet sejt- és szövetkivonatok előtisztítására. 


\section{Célkitűzések}

A disszertáció a kismolekuláknak, mint molekuláris biológiai eszközöknek az alkalmazásával foglalkozik két fó témakörben. Az egyik ilyen terület az új fluoreszcens festékek felfedezése a kismolekula microarray és a konfokális pásztázó mikroszkópia kombinált módszerével, a másik pedig a kismolekulákkal kapcsolt affinitás töltetek létrehozása és alkalmazása.

\subsection{Kismolekula microarray és konfokális pásztázó mikroszkópia együttes alkalmazása élő sejteket festő fluoreszcens markerek azonosítására}

Az általunk készített, gyógyszerjelölt molekulák szürésére tervezett kismolekula microarray-ek több olyan vegyületet tartalmaznak, amelyek erős természetes fluoreszcenciával rendelkeznek. Ez a tulajdonságuk alkalmatlanná teszi a molekulákat arra, hogy hitazonosítási kísérletekben szerepeljenek, de megnyitja az utat intracelluláris festékként történő alkalmazásuk elött. Ezért elhatároztuk, hogy kidolgozunk egy kombinált módszert, ahol a microarray és a konfokális pásztázó mikroszkópia együttes használatával új fluoreszcens festékeket fedezhetünk fel.

\subsection{Speciális felülethez kapcsolt kismolekulák alkalmazása affinitás kromatográfiában}

\subsubsection{AviLink felületmódosítással ellátott affinitás töltet előállítása és felhasználása célpontazonosításban}

A gyógyszerkutatás fontos lépése a gyógyszerjelölt molekulához kötődő fehérjék affinitás kromatográfiával történő azonosítása. Megvizsgáltuk, hogy az általunk kifejlesztett és kismolekula microarray-ek formájában már rutinszerüen alkalmazott AviLink felületmódosítás alkalmas-e affinitás töltet elöállítására, illetve az így létrehozott töltet megfelelhet-e célpontfehérjék meghatározására. 


\subsubsection{Nem-specifikusan kötődő fehérjék eltávolítása sejt- és szövetkivonatokból 2-aminobenzimidazollal kapcsolt affinitás töltettel}

Az affinitás kromatográfia legnagyobb korlátozó tényezője az abundáns fehérjék nem-specifikus kikötődése az affinitás tölteten. Célunk az volt, hogy ennek a problémának a megoldására egy olyan előtisztító töltetet fejlesszünk ki, amely képes megkötni a sejtekben nagy mennyiségben jelenlévő tubulint, amely megnehezíti a gyakran csak kis mennyiségben jelenlévő intracelluláris gyógyszercélpontok azonosítását. 


\section{Anyagok és módszerek}

\subsection{Kémiai könyvtárak}

A kísérleteinkben használt kismolekula microarray-ek nagyobb részt kereskedelmi forgalomban lévő molekulákból álltak: 8800 db vegyületet a Nanosyn (USA), 5120 db-ot pedig az Enamine (Ukrajna) cégtől vásároltunk. 665 db molekula az Avidin Kft. vegyülete volt.

\subsection{Kismolekula microarray-ek előállítása}

Szabadalmaztatott technológiánkkal (AviLink) kémiailag aktivált lemezeket állítottunk elö, amelyek alkalmasak nagy sürüségü kismolekula microarray-ek készítésére. Mikroszkóp tárgylemezeket egy éjszakán át 10\%-os vizes $\mathrm{NaOH}$-oldatban áztattunk, majd vízzel, 1\%-os vizes $\mathrm{HCl}$-oldattal, majd újra vízzel addig mostuk azokat, amíg a mosóoldat kémhatása semleges lett. Ezt követően a lemezeket szobahőmérsékleten megszárítottuk. Az üveglemezeket ezután 95\%-os vizes metanolban készített 3\%-os N-(2-aminoetil)-3aminopropil-trimetoxiszilán-oldattal reagáltattuk 2 órán keresztül, ezután metanollal, majd vízzel mostuk, megszárítottuk és $105^{\circ} \mathrm{C}$-on 15 percig hőkezeltük azokat. Ezt követően a lemezekre a következö elegyet vittük fel: $8 \mathrm{mmol}$ akrilsavklorid, $8 \mathrm{mmol}$ epiklórhidrin, 8 mmol klóracetonitril, 8 mmol klórecetsavklorid, $32 \mathrm{mmol}$ diizopropil-etil-aminnal $100 \mathrm{ml}$ diklóretánban, majd 2 órán keresztül inkubáltuk azokat szobahömérsékleten. Ezután a lemezeket 5x100 ml diklóretánnal mostuk és szobahőmérsékleten megszárítottuk.

A kismolekulákból dimetil-szulfoxidban (DMSO) $5 \mathrm{mM}$ koncentrációjú oldatokat készítettünk, majd ezekből az oldatokból 20-20 $\mu$ l-t 384 lyukú lemezekbe mértünk. A lemezekből MicroGrid II (BioRobotics, Egyesült Királyság) mechanikus csipnyomtató robottal (24 db kapilláris tủvel, prespot funkcióval, szobahőmérsékleten, 50\% páratartalom mellett) az aktivált üveg tárgylemezekre nyomtattunk. A molekulákból kettő vagy négy párhuzamost nyomtattunk; a pontok átmérője kb. $150 \mu \mathrm{m}$ volt. 


\subsection{A fluoreszcencia intenzitások mérése és kiértékelése}

A lenyomtatott microarray-eket egy Agilent G2505B Microarray Scanner-rel (lézerek: $532 \mathrm{~nm}$ SH-YAG és $633 \mathrm{~nm}$ HeNe) olvastuk le $10 \mu \mathrm{m}$-es felbontás és maximális lézerteljesítmény mellett. A képek kiértékeléséhez az Agilent (Németország) Feature Extraction és az Axon Laboratory (USA) GenePix Pro 6.0 programját használtuk.

\subsection{Sejtkultúra kezelések}

A sejtkultúra kezeléseket az SZBK Mikroszkópos Sejtanalízis Laboratóriumának munkatársai végezték. A HeLa humán cervikális karcinóma sejteket $2 \mathrm{mM}$ glutamint, 10\% fötális borjúszérumot, $100 \mathrm{U} / \mathrm{ml}$ penicillint és $100 \mu \mathrm{g} / \mathrm{ml}$ sztreptomicint tartalmazó Dulbecco által módosított Eagle's médiumban (DMEM, Lonza, Svájc) tenyésztették $37{ }^{\circ} \mathrm{C}-o n$ 5\% $\mathrm{CO}_{2}$ és $85 \%$ páratartalom mellett. Az egynapos kultúrákat 1-2 órán (rövid inkubáció) illetve egy napon (hosszú idejü inkubáció) át kezelték 1 és $10 \mu \mathrm{M}$ koncentrációjú kismolekulákkal 96 lyukú üvegaljú lemezen (Greiner Bio-One, Ausztria) vagy LabTek 8 lyukú kamrákban (Nalge Nunc International, USA). Kontroll kezelésként 1\% DMSO-t alkalmaztak. A C2 vegyület fotokonverzióját folyamatos $633 \mathrm{~nm}$-es szkenneléssel (HeNe lézer, 50\% lézerintenzitás) vagy rodamin filterbeállítások $(510-550 \mathrm{~nm})$ melletti 10 másodperces gerjesztéssel egy HBO 103W/2 (Osram, Németország) rövid ívü higanyizzó maximális intenzitású használatával érték el. A C2 vegyület alacsony lézerintenzitásnál tapasztalt stabilitását $633 \mathrm{~nm}$-en, 4\%-os lézerintenzitással történő folyamatos szkenneléssel mutatták be.

A kolokalizációs vizsgálatok során a Hoechst 33342 (Invitrogen, USA) interkalálódó festéket alkalmazták $1 \mu \mathrm{M}$ koncentrációban a sejtmagok in vivo festésére. A mitokondriumok jelölésére $0.2 \mu \mathrm{M}$ MitoTracker Orange-et (Invitrogen, USA) illetve $0.5 \mu \mathrm{M}$ nonil-akridin-narancsot (NAO, Sigma-Aldrich, USA) használtak. A sejtek kiemelését 0.1 $\mu \mathrm{M}$ fluoreszcein diacetáttal (FDA, Sigma-Aldrich, USA) végezték. A RedDot 1 (Biotium, USA) sejtmagi markert a gyártó javaslatának megfelelően 200x hígításban alkalmazták. A lipidcseppecske-kolokalizációs kísérleteket és az apoptotikus sejtmagok analízisét fixált sejteken végezték: a sejteket PBS-ben oldott 4\%-os paraformaldehidben fixálták 7 percen át szobahőn, majd a fixálót háromszor 5 perces PBS-es mosással távolították el. A lipidcseppecske-kolokalizációs kísérletekhez az Oil Red O 1\%-os oldatát készítették el 
izopropanolban. A sejteket először a vizsgált fluorokrómmal inkubálták 10 percig, majd Oil Red O-t cseppentettek 0.01\%-os végkoncentrációban a kamra közepére. A középső, izopropanolos oldatnak kitett rész körüli régión végezték a kolokalizációs analízist. Az apoptotikus magok vizsgálatához HeLa sejteket inkubáltak 24 órán át a vizsgált vegyülettel $10 \mu \mathrm{M}$ (a $\mathrm{C} 2$ és a $\mathrm{C} 2 *$ vegyület esetében $1 \mu \mathrm{M}$ ) koncentrációban. PBS-es mosásokat követően a sejteket fixálták és $0.1 \mu \mathrm{g} / \mathrm{ml}$ DAPI-val (Sigma-Aldrich, USA) 10 percig festették azokat.

\subsection{Konfokális pásztázó mikroszkópia}

A mikroszkópos vizsgálatokat az SZBK Mikroszkópos Sejtanalízis Laboratóriumának munkatársai végezték. A vizsgálatokban használt Olympus Fluoview FV1000 konfokális pásztázó mikroszkóp (Olympus Life Science Europa GmbH, Németország) beállításai a következők voltak: objektívek: UPLSAPO 20x (száraz, NA:0.75), UPLFLN 40x (olaj, NA:1.3) és UPLSAPO 60x (olaj, NA:1.35); mintavételi sebesség: 4 $\mu \mathrm{s} /$ pixel; 2x soronkénti átlagolás; szkennelési mód: szekvenciális egyirányú; gerjesztés: 405 nm (Hoechst 33342, DAPI és az új vegyületek kék fluoreszcenciájának detektálása), 488 nm (NAO, FDA és zöld fluoreszcencia detektálás), $543 \mathrm{~nm}$ (Oil Red O, MitoTracker Orange és vörös fluoreszcencia detektálás) és $633 \mathrm{~nm}$ (Red Dot 1 és távoli vörös fluoreszcencia detektálás); maximális lézer-áteresztőképesség értékek: 2\% (405 nm), 5\% (488 nm), 50\% $(543 \mathrm{~nm})$ és 50\% (633 nm); emissziós filterek: kék: $425-475 \mathrm{~nm}$, zöld: 500-530 nm; vörös: 555-625 nm, távoli vörös: $\lambda>650 \mathrm{~nm}$. Az egy napig kezelt sejtek vizsgálata elött a detektor résének átméröjét (1 Airy egység) két-háromszorosára növelték, hogy be tudják fogni a gyenge fluoreszcenciát. A hamisszínes képeket az Olympus Fluoview szoftverével $(2.0 \mathrm{c}$ verzió) állították elö.

\subsection{Teljes fehérjekivonat előállítása patkány májból}

5 hím Wistar patkány (Charles River, USA) máját A pufferben (10 mM HEPES pH 7.5, $100 \mathrm{mM} \mathrm{NaCl}, 2 \mathrm{mM} \mathrm{MgCl} 2,1 \mathrm{mM}$ etilénglikol-tetraecetsav (EGTA), Complete Protease Inhibitor Cocktail Tablet (Roche Diagnostics, Németország) homogenizáltuk egy Braun Teflon-üveg homogenizálóval (10 000 rpm jégen). A kapott homogenátumot $45000 \mathrm{x}$ g-n 30 percen át centrifugáltuk. A pelletet $10 \mathrm{ml}, 1 \%$ Triton X-100-at tartalmazó A pufferrel 
felszuszpendáltuk, majd 30 percig $4{ }^{\circ} \mathrm{C}$-on inkubáltuk állandó rázatás mellett. Ezután a szuszpenziót 45000 x g-n 30 percig centrifugáltuk. A felülúszót összegyüjtöttük, és tovább centrifugáltuk 147000 x g-n 30 percig. A kapott felülúszót összegyüjtöttük, és célpontazonosításban használtuk fel.

\subsection{Ac-2010-zel kapcsolt affinitás töltet előállítása}

AviLink technológiával aktivált CPG-t állítottunk elő (a lépések megegyeztek a 3.2. fejezetben leírtakkal). $10 \mathrm{mg}$ Ac-2010-et oldottunk fel $5 \mathrm{ml}$ diklórmetánban, majd az oldatot 1 g AviLink-CPG-hez öntöttük és sürü rázogatás mellett 1 percig forraltuk. Miután szobahőmérsékletüre hült, az oldatot leöntöttük, az üvegszemcséket pedig alaposan lemostuk diklórmetánnal, metanollal és végül desztillált vízzel. A töltetet a száradást követően célpontazonosításban alkalmaztuk.

\subsection{Affinitás kromatográfia}

Az Ac-2010 affinitás töltet 1 ml-ét kisméretü polipropilén kolonnába töltöttük, majd PBS-sel ekvilibráltuk. A májkivonatot Complete Protease Inhibitor Cocktail Tablet-et (Roche Diagnostics, Németország) tartalmazó PBS-sel $5 \mathrm{mg} / \mathrm{ml}$ koncentrációjúra hígítottuk, majd a felét felvittük a töltetre és hagytuk átfolyni azon. Ezután az oszlopot először $10 \mathrm{ml}$ PBS-sel, majd 10-10 ml 0.2 és 0.5 M NaCl-ot tartalmazó PBS-sel mostuk. Ezt követően az Ac-2010 $1 \mathrm{mg} / \mathrm{ml}$-es oldatával (0.5 M NaCl-ot tartalmazó PBS-ben) kompetitív elúciót végeztünk, majd a töltetet $1 \mathrm{M}$ NaCl-ot tartalmazó PBS-sel, végül pedig 1\% SDS-sel eluáltuk. 1 ml-es frakciókat szedtünk. Ezzel párhuzamosan a hígított májkivonat másik felével egy Ac-2010-et nem tartalmazó (kontroll) tölteten is elvégeztük a kísérletet. A frakciókat méretkizárásos membrán segítségével (Microcon-10kDa Centrifugal Filter Unit with Ultracel-10 membrane, Merck Millipore, Németország) egy század térfogatúra töményítettük be.

\section{9. $\quad$ SDS-poliakrilamid gélelektroforézis (SDS-PAGE)}

A betöményített frakciókat azonos térfogatú (10 $\mu \mathrm{l})$ Laemmli-pufferrel $100{ }^{\circ} \mathrm{C}$-on 5 percig denaturáltuk, majd a teljes, $20 \mu$ l-es mintamennyiségeket SDS-PAGE-vel analizáltuk. Ehhez az Ac-2010 és a kontroll töltetről kapott mintákat egymás mellett futtattuk grádiens 
gélen (4-12 \% Tris-Glycine PAGEr Gold Precast Gels, Lonza, Svájc) molekulasúly marker (PageRuler Unstained Protein Ladder, Fermentas, Litvánia) jelenlétében 50 V-on 15 percig, majd $80 \mathrm{~V}$-on 90 percig. A gélelektroforézist követően a géleket megfestettük (PageBlue Protein Staining Solution, Fermentas, Litvánia) és a specifikus sávokat (amik jelen voltak az Ac-2010 mintában, de a konrollban nem) a hozzájuk tartozó „üres” kontroll sávokkal együtt a gélből kivágtuk.

\subsection{Tömegspektrometriai elemzés}

A tömegspektrometriás meghatározásokat az SZBK Proteomikai Kutatócsoportjának munkatársai végezték. A kivágott géldarabok fehérjetartalmát gélben emésztették oldalláncvédett tripszinnel, a University of California (San Francisco, USA) honlapján (http://msf.ucsf.edu/ingel.html) ismertetett protokollban leírtak szerint. A kapott triptikus emésztményeket mátrixszal segített lézer deszorpciós ionizáció repülésidő tömegspektrometriával (MALDI-TOF MS) vagy folyadék kromatográfiatandem tömegspektrometriával (LC-MS/MS) analizálták.

\subsection{Protein diszulfid izomeráz (PDI) enzimaktivitás mérése inzulin- turbidimetriával}

A módszer alapja az inzulin katalitikus redukciójának mérése Lundström és Holmgren leírása szerint [65]. A PDI DTT jelenlétében katalizálja az inzulin diszulfidhídjainak redukcióját, majd a redukált inzulin láncok aggregálódnak, ami a turbiditás spektrofotometriás mérésével követhetö. A kísérleteket 96-lyukú lemezekben végeztük 30 $\mu 1$-es térfogatokban, $1 \mathrm{mM}$ DTT-t, $1 \mu \mathrm{g}$ PDI-t (Sino Biological, Kína), $0.14 \mathrm{mM}$ marha inzulint (Sigma-Aldrich, USA), és $0.2 \mathrm{mM}$ etiléndiamin-tetraecetsavat (EDTA) tartalmazó 100 mM, pH 7.0 nátrium-foszfát pufferben. A reakció előrehaladását egy 96-lyukú lemezek mérésére alkalmas müszeren (Model 680 Microplate Reader, Bio-Rad, USA) követtük 340 nm-en 100 percen át szobahőmérsékleten. A DMSO-ban oldott Ac-2010-et illetve a tiszta DMSO kontrollt az enzim hozzáadása előtt mértük a reakcióelegyekhez. Az inzulin nemenzimatikus redukcióját egy PDI-t nem tartalmazó kontrollban vettük fel. Az Ac-2010 IC 50 értékét a különböző koncentrációjú kezelésekhez tartozó görbék nemlineáris regressziós analízisével számítottuk ki. 


\subsection{2-aminobenzimidazollal kapcsolt affinitás töltet előállítása}

20 g CPG-t (3Prime, USA) egy 500 ml-es Erlenmeyer-lombikban 1 órán át rázattunk $200 \mathrm{ml}, 3 \%$ 3-aminopropil-trimetoxiszilánt (Sigma-Aldrich, USA) tartalmazó 95\%-os metanolban. Az így kapott töltetet metanollal, majd vízzel mostuk, azután 15 percig $100{ }^{\circ} \mathrm{C}$ on hökezeltük blokkfütőn. Ezután az amino-szilanizált CPG-t 2 órán át $100 \mathrm{ml}, 15 \%$ izoftálsav-dikloridot (Sigma-Aldrich, USA) tartalmazó diklórmetánnal rázattuk, majd mostuk diklórmetánnal és metanollal, azután vákuum alatt megszárítottuk. Az izoftál-CPG-t 2 órán át $100 \mathrm{ml}, 5 \%$ 2-aminobenzimidazolt (Sigma-Aldrich, USA) tartalmazó diklórmetánban rázattuk, majd mostuk és szárítottuk az előző lépésben leírtak szerint. A 2aminobenzimidazollal nem fedett aktivált csoportokat 2 órán át blokkoltuk $100 \mathrm{ml}, 5 \%$ etanolamint tartalmazó diklórmetánban, majd a töltetet az előző lépéssel megegyezően mostuk és szárítottuk.

\subsection{A széntartalom meghatározása és a felületi lefedettség kiszámítása}

Az affinitás töltet elöállításának lépései során keletkezett termékek (amino-CPG, izoftál-CPG，2-aminobenzimidazol-CPG) széntartalmának meghatározását a Debreceni Egyetem Agrokémiai és Talajtani Intézetének munkatársai végezték egy Vario Macro CNS elemanalizátorral (Elementar, Németország). A kapott adatokból a natív CPG specifikus felületének ismeretében (a gyártó által megadva: $51 \mathrm{~m}^{2} / \mathrm{g}$ ) a kiterjesztett Berendsen-de Galan egyenletek [66] alapján kiszámítottuk az egyes termékek felületi lefedettségét.

\subsection{Teljes fehérjekivonat előállítása állati szövetből és humán sejtkultúrából depléciós kísérletekhez}

5 hím Wistar patkány (Charles River, USA) agyából a 3.6. fejezetben leírtakkal megegyezően készítettünk teljes fehérjekivonatot, amelyet a depléciós kísérletben használtuk fel.

Az A549 humán tüdő karcinóma sejteket (Sigma-Aldrich, USA) $37{ }^{\circ} \mathrm{C}-$ on, $5 \% \mathrm{CO}_{2}$ és $85 \%$ páratartalom mellett, $10 \%$ fötális borjúszérumot, $100 \mathrm{U} / \mathrm{ml}$ penicillint és $100 \mu \mathrm{g} / \mathrm{ml}$ sztreptomicint tartalmazó DMEM-ben tenyésztettük, amíg a sejtek szinte teljesen benőtték a csésze felületét. A sejteket kétszer mostuk PBS-sel, majd 1000 rpm-en 5 percig 
centrifugáltuk. Ezután a PBS-t leöntöttük, és a sejteket felszuszpendáltuk másfélszeres térfogatú A oldatban (50 mM HEPES pH 8.0, $10 \mathrm{mM} \mathrm{KCl,} 1 \mathrm{mM}$ EGTA, $1 \mathrm{mM}$ DTT, Complete Protease Inhibitor Cocktail Tablet, Roche Diagnostics, Németország), majd 10 percig jégben inkubáltuk. Ezután $0.5 \%$ TritonX-100-at adtunk a szuszpenzióhoz, alaposan összekevertük, majd egy rövid, 6000 rpm-en történő centrifugálást követően a felülúszót összegyüjtöttük, és ezt vittük fel a depléciós kísérletben a 2-aminobenzimidazollal kapcsolt oszloptöltetre.

\subsection{Nem-specifikusan kötődő fehérjék depléciója 2-aminobenzimidazol töltettel}

A 2-aminobenzimidazollal kapcsolt affinitás töltetet $(1 \mathrm{ml})$ kisméretü polipropilén kolonnába töltöttük, majd PBS-sel ekvilibráltuk. A nyers sejt- illetve szövetkivonatot PBSsel $8 \mathrm{mg} / \mathrm{ml}$ koncentrációjúra hígítottuk, majd felvittük az oszlopra és hagytuk átfolyni azon. Ezután az oszlopot először $10 \mathrm{ml}$ PBS-sel, majd $10 \mathrm{ml} 0.5 \mathrm{M}$ NaCl-ot tartalmazó PBS-sel mostuk. Az összes oszlopon átfolyt oldatot egybegyüjtöttük, és "átfolyó frakciónak" neveztük el.

\subsection{Kétdimenziós gélelektroforézis}

$60 \mu \mathrm{g}$ fehérjét tartalmazó oldatot ReadyPrep 2-D Cleanup Kittel (Bio-Rad, USA) kicsapattunk, majd $150 \mu 1$ minta rehidráló pufferben (7 M urea, $2 \mathrm{M}$ tiourea, 4\% CHAPS, $50 \mathrm{mM}$ ditiotreitol (DTT) és egy csipet brómfenolkék) visszaoldottuk. A feloldott mintát egy éjszakán át szobahőmérsékleten inkubáltuk ReadyStrip immobilizált pH-grádiens (IPG) csíkkal (pH 3-10, 7 cm, Bio-Rad, USA). A rehidrációt követően izoelektromos fókuszálást végeztünk (20 perc 0-250 V lineárisan; 2 óra 250-4000 V lineárisan; 2.5/4.5 óra $4000 \mathrm{~V}$ ) 20 ${ }^{\circ} \mathrm{C}$-on egy PROTEAN IEF Cell-ben (Bio-Rad, USA). Az első dimenziós elválasztás után az IPG csíkban lévő fehérjéket DTT-t tartalmazó ekvilibráló pufferrel (6 M urea, $0.375 \mathrm{M}$ Tris/HCl, pH 8.8, 5\% SDS, 30\% glicerol, 2\% DTT és egy csipet brómfenolkék) redukáltuk, majd jódacetamidot tartalmazó ekvilibráló pufferrel $(6 \mathrm{M}$ urea, $0.375 \mathrm{M}$ Tris/ $\mathrm{HCl}, \mathrm{pH} 8.8$, 5\% SDS, 30\% glicerol, 5\% jódacetamid és egy csipet brómfenolkék) alkiláltuk két-két alkalommal 10 percen át. A második dimenziós elválasztás Mini-PROTEAN Tetra Systemmel (Bio-Rad, USA) történt. Az IPG csíkot egy 9\%-os SDS-poliakrilamid gél tetejére 
helyeztük, majd ReadyPrep Overlay agarózzal (Bio-Rad, USA) fedtük be. Az elektroforézist 20 percig 70 V-on, ezután pedig $110 \mathrm{~V}$-on végeztük addig, amíg a festék elérte a gél alját. A gélt 50\% metanolt és 5\% ecetsavat tartalmazó oldatban fixáltuk, majd kolloidális Silver Blue-val festettük. A megfestett gélt VersaDoc MP 4000 Imaging System (Bio-Rad, USA) és PDQuest Advanced 8.0.1 2D Gel Analysis Software (Bio-Rad, USA) felhasználásával analizáltuk. Az azonosításra szánt fehérjefoltokat kivágtuk és tömegspektrometriás elemzésre küldtük (lásd a 3.10. fejezetet). 


\section{Eredmények és diszkusszió}

\subsection{Kismolekula microarray és konfokális pásztázó mikroszkópia együttes}

alkalmazása élő sejteket festő fluoreszcens markerek azonosítására

14585 darab kismolekulát nyomtattunk kémiailag módosított üvegfelületre kétilletve négyszeres ismétlésben. Az így elöállított kismolekula microarray-eket egy kétcsatornás, zöld (532 nm-es hullámhosszú) és vörös (633 nm-es hullámhosszú) lézerekkel és megfelelő szürőkkel ellátott microarray szkennerrel olvastuk be (4. ábra). Azokat a molekulákat, amelyek csak más hullámhosszakon gerjeszthetők, a szkenner nem képes detektálni, így ezek a további vizsgálatok számára elvesznek. Ez a probléma megoldható egy több lézerrel felszerelt szkenner használatával, amely az UV-tól a távoli vörös tartományig lefedi a spektrumot.

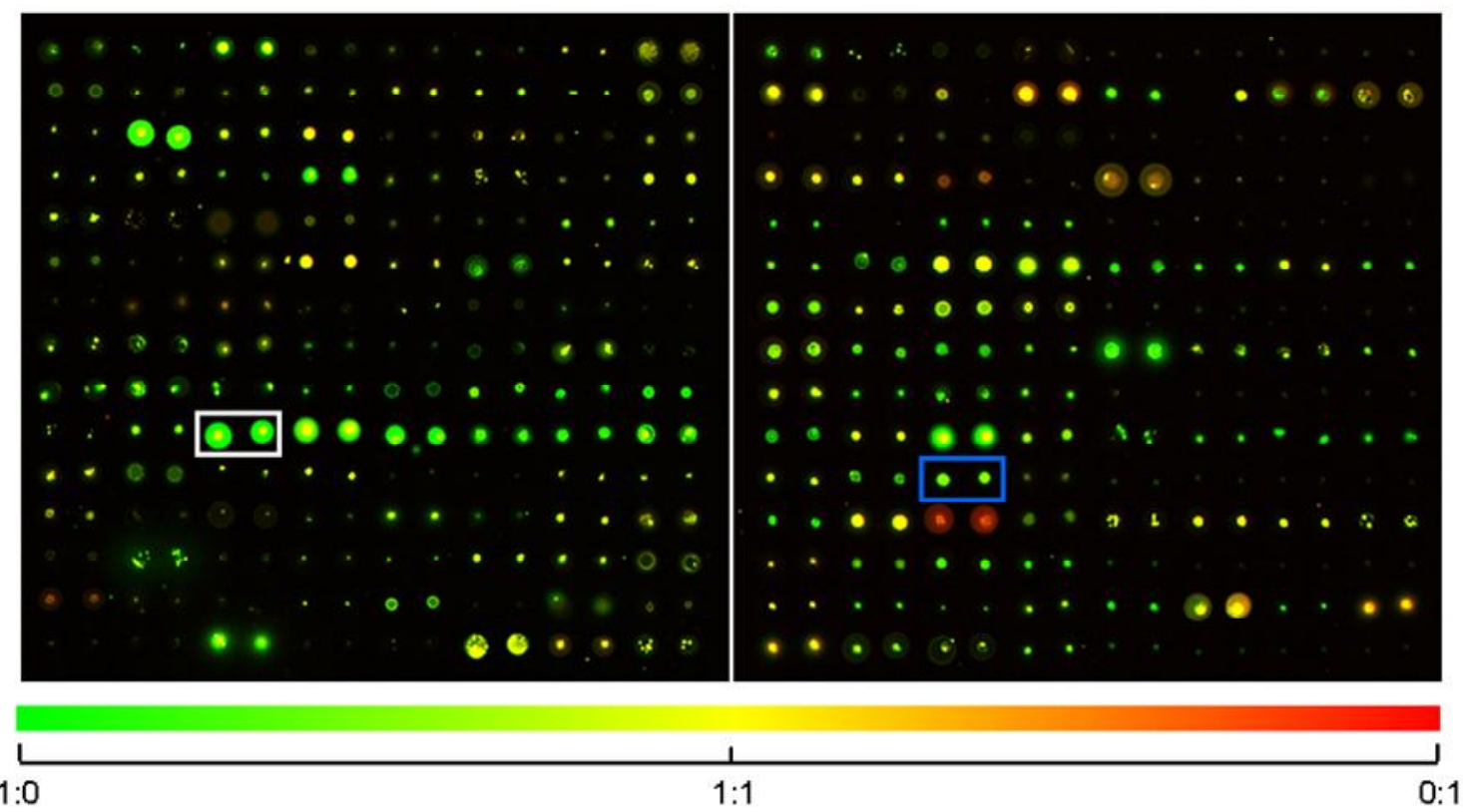

4. ábra. Két kismolekula microarray blokk 532 és $633 \mathrm{~nm}$ hullámhosszú lézerrel gerjesztett hamisszínes képe. A pontok színe az 570 és 670 nm-en mért fluoreszcencia arányának felel meg, ahogy az alsó színskála mutatja. A téglalapok két kiválasztott molekulához tartozó párhuzamos pontokat jelölnek (fehér: D10, kék: E5). 
A szkennelt képeket szoftveres analízisnek vetettük alá, amely során azonosítottuk a pontok helyét, a hozzájuk tartozó jel- és háttérintenzitásokat, valamint meghatároztuk ezek statisztikai paramétereit. Ezután kiszürtük azokat a pontokat, amelyek jelen voltak, magas (>2) volt a jel-zaj arányuk és a szignifikanciájuk (vagyis legalább a pixelek 60\%-ának intenzitása haladta meg a háttér + kétszeres standard deviáció értékét) és erős jelet adtak (a háttérrel korrigált jelintenzitás mediánja >500). Ezt a szürést mindkét vizsgált hullámhosszon (532 és $633 \mathrm{~nm}$ ) elvégeztük. Azokat a kismolekulákat, amelyeknél legalább két (kétszeres ismétlésnél) vagy három (négyszeres ismétlésnél) párhuzamos pont teljesítette a szürési feltételeket legalább az egyik hullámhosszon, kiválogattuk mikroszkópos vizsgálatra. A 4. ábrán két kiválasztott molekulához tartozó pontok láthatók.

Bár a fluoreszcens molekulákat 532 és 633 nm-es lézerek segítségével szelektáltuk, a további vizsgálat során a konfokális mikroszkóp mind a négy lézerét (405, 488, 543 és 633 nm) használtuk, mivel bizonyos fluorokrómoknak több gerjesztési vagy emissziós csúcsa is lehet. Például az R-fikoeritrin abszorpciós spektruma két különálló csúcsot (480 illetve 565 $\mathrm{nm)} \mathrm{tartalmaz.} \mathrm{Ráadásul} \mathrm{több} \mathrm{olyan} \mathrm{fluoreszcens} \mathrm{próba} \mathrm{is} \mathrm{ismert,} \mathrm{amely} \mathrm{az} \mathrm{élő} \mathrm{sejtek}$ molekuláival kölcsönhatva megváltoztatja spektrális tulajdonságait. Ennek jó példája az akridin-narancs nevü festék, amelynek emissziós csúcsa attól függően változik, hogy DNSsel $(530 \mathrm{~nm})$ vagy RNS-sel $(640 \mathrm{~nm})$ hat kölcsön. A sejten belüli ionkoncentrációk és pH, valamint a kompartmentalizáció szintén befolyásolhatja egyes fluorokrómok sajátságait [67].

278 fluoreszcens vegyületet azonosítottunk a kismolekula microarray-ek segítségével, majd ezeket elöször fluoreszcencia intenzitás, sejtpermeabilitás, oldhatóság és toxicitás szempontjából vizsgáltuk meg in vivo körülmények között HeLa sejteken konfokális pásztázó mikroszkóppal. Azokkal a molekulákkal, amelyek nem jutottak be a sejtekbe, toxikusak voltak vagy rosszul oldódtak, nem foglalkoztunk tovább. Néhány festék az élö sejtekben csak gyenge fluoreszcenciát mutatott. Ennek oka lehet a vegyület alacsony permeabilitása vagy más molekulákkal való kölcsönhatása a médiumban illetve a sejt belsejében. Ezeket a molekulákat sem vizsgáltuk tovább, mivel a nagy energiájú gerjesztés, amelyet ezek a vegyületek a megfelelő mértékü emisszió kiváltásához igényelnének, negatív hatást gyakorolhatna a sejtek metabolizmusára vagy életképességére. Végül 11 olyan fluoreszcens molekulát találtunk (1. táblázat), amelyek megfeleltek a szigorú kiválasztási feltételeknek, így ezeken végeztük további vizsgálatainkat. 


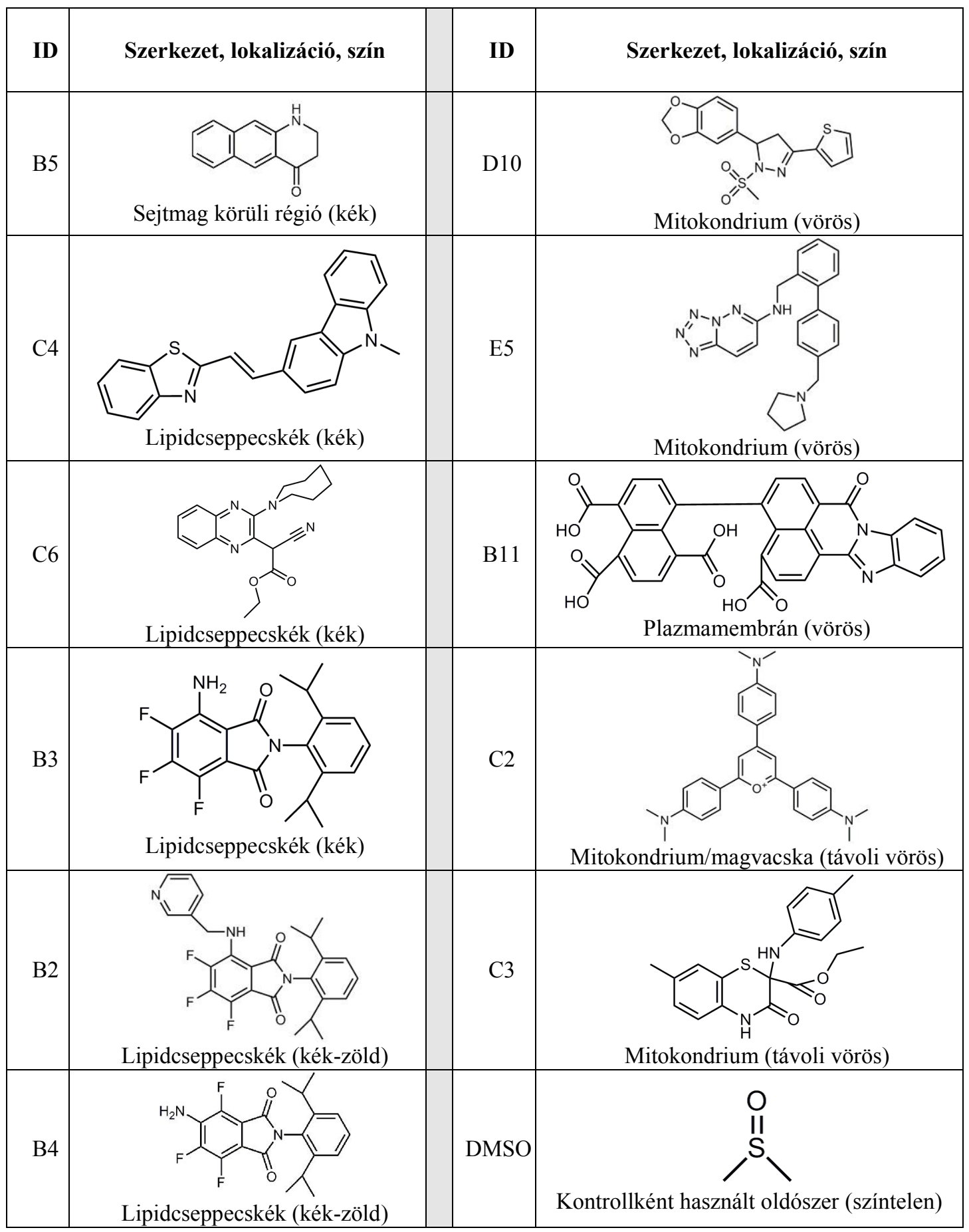

1. táblázat. A kiválasztott molekulák és a kontrollként használt DMSO kémiai szerkezete és jelölési tulajdonságai.

A 11 vegyület emisszióját négy csatornán (kék, zöld, vörös, távoli vörös), 405, 488, 543 és 633 nm-es gerjesztés mellett vettük fel. Közülük öt a lipidcseppecskékkel, három a mitokondriumokkal, egy a plazmamembránnal, egy a sejtmag körüli régióval, egy pedig - a 
lézeres gerjesztéstől függően - a mitokondriumokkal illetve a sejtmagvacskákkal és a citoplazmával mutatott kolokalizációt (1. táblázat). A mikroszkópos képalkotás gerjesztési és detektálási küszöbértékeinek beállításához DMSO-val kezelt sejteket használtunk referenciaként. Mindegyik vegyület festette 1 órás $37{ }^{\circ} \mathrm{C}$-os inkubáció alatt az adott kompartmentet $10 \mu \mathrm{M}$ koncentrációban alkalmazva. A C2 molekula még $0.25 \mu \mathrm{M}$ koncentrációban is erős jelet adott, így - mivel a sejtek ezt a vegyületet nem tolerálták jól 10 $\mu \mathrm{M}$ koncentrációban $-1 \mu \mathrm{M}$-ra korlátoztuk a használatát. A vegyületek stabilitását és a jelölés perzisztenciáját is megvizsgáltuk. Az E5, a D10 és a C3 kivételével valamennyi molekula fluoreszkált még 1 napos $37^{\circ} \mathrm{C}$-os inkubációt követően is.

A fluoreszcens molekulák intracelluláris lokalizációját ismert fluoreszcens markerek segítségével határoztuk meg (5. ábra). Az 5/1. ábra a sora egy DNS-specifikus sejtmagi markerrel, a RedDot 1-gyel és a sejtmag körüli régióval asszociálódó B5 vegyülettel együtt festett sejteket mutat. Az 5/1. ábra b-d és az 5/2. ábra e-f soraiban látható a lipidcseppecskék Oil Red O festésének kolokalizációja a C4, C6, B2, B3 és B4 vegyületekkel, fixált sejteken. A B2-B4 molekulák az Avidin Kft. nem-random szintetizált gyüjteményéből származnak néhány más trifluoro-amino-ftálimid analóggal együtt, amelyeket egy másik projektünkben potenciális tumorellenes hatóanyagokká fejlesztettünk [68]. Ezért a B2-B4 molekuláknak ugyanaz az alapváza (1. táblázat), ellentétben a másik nyolc fluorokrómmal, amelyek kereskedelmi forgalomban lévő könyvtárakból lettek kiválasztva. Az Oil Red O-tól eltérően mind az öt lipidcseppecske-jelölő vegyület sejtpermeábilis, így használatukhoz nincs szükség a sejtek fixálásra, ezáltal lehetővé teszik a lipidcseppecskék in vivo lokalizációjának, mobilitásának és dinamikájának analízisét. Az 5/2. ábra g-h és az 5/3. ábra i-k soraiban öt másik élő sejt-markert láthatunk. A D10, E5, C2 és C3 vegyületek mind a mitokondriumokhoz lokalizálódtak, amit a vörösben emittáló D10 és E5 vegyületeknek a zöld nonil-akridin-naranccsal (NAO) (5/2. ábra $\mathbf{g}$-h) és a távoli vörös fluoreszcenciát mutató C2 és C3 molekuláknak a vörös MitoTracker Orange markerrel (5/3. ábra j-k) végzett kolokalizációs vizsgálata is megerősített. A B11 molekula a plazmamembránt festette (5/3. ábra i), és fluoreszcenciája még egynapos inkubáció után is látható maradt a sejtek életképességének rontása nélkül, így ez a festék használható lehet hosszútávú sejtjelölési és követési kísérletekben is. A B11 vegyület lokalizációját a teljes sejtet festő FDA-val határoztuk meg (5/3. ábra i). 


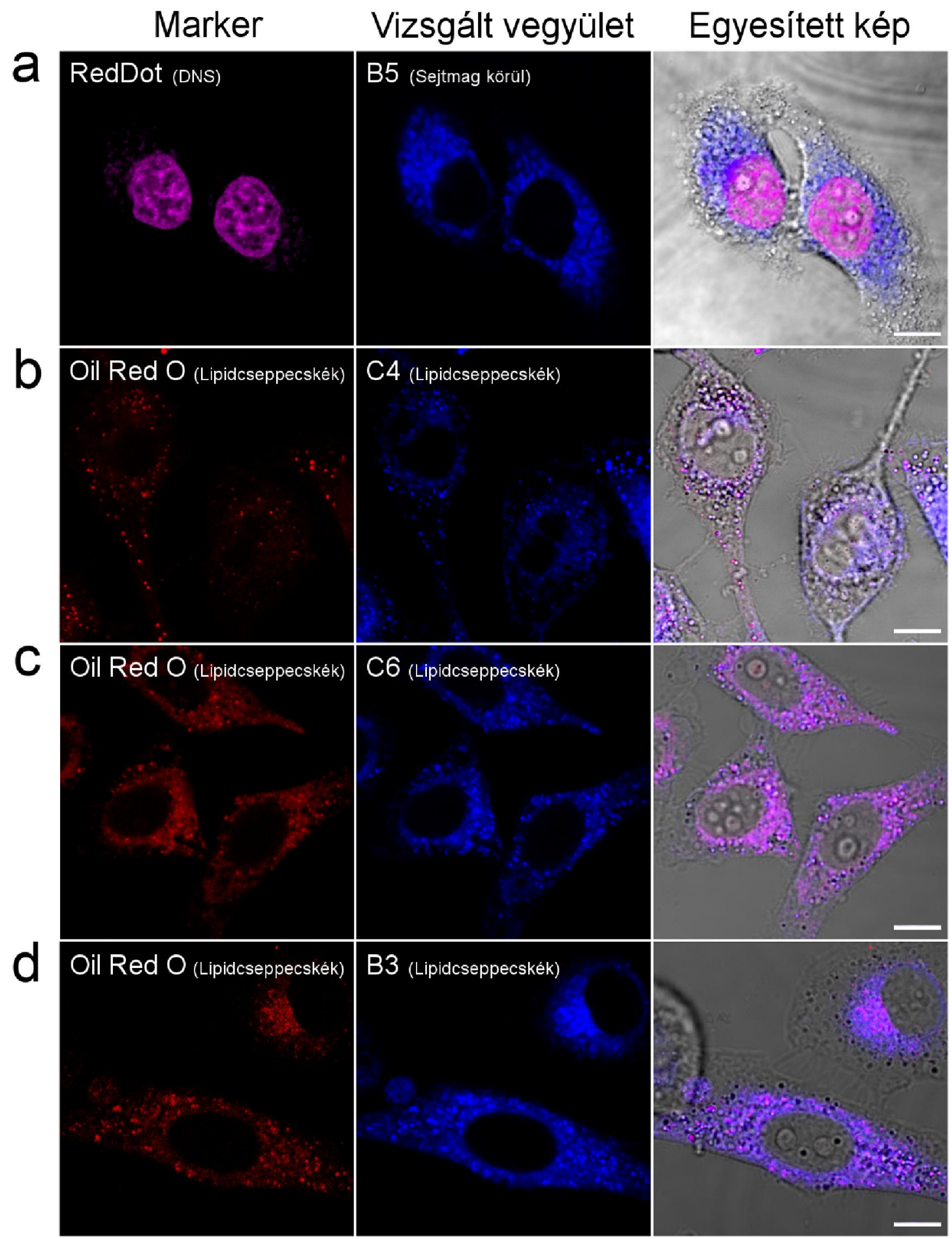

5/1. ábra. A vizsgált vegyületek kolokalizációja ismert markerekkel. A lokalizációt az ábrán feliratoztuk. Élő (a) illetve fixált sejteket (b-d) használtunk a vizsgálatokhoz. Skála: $10 \mu \mathrm{m}$. 


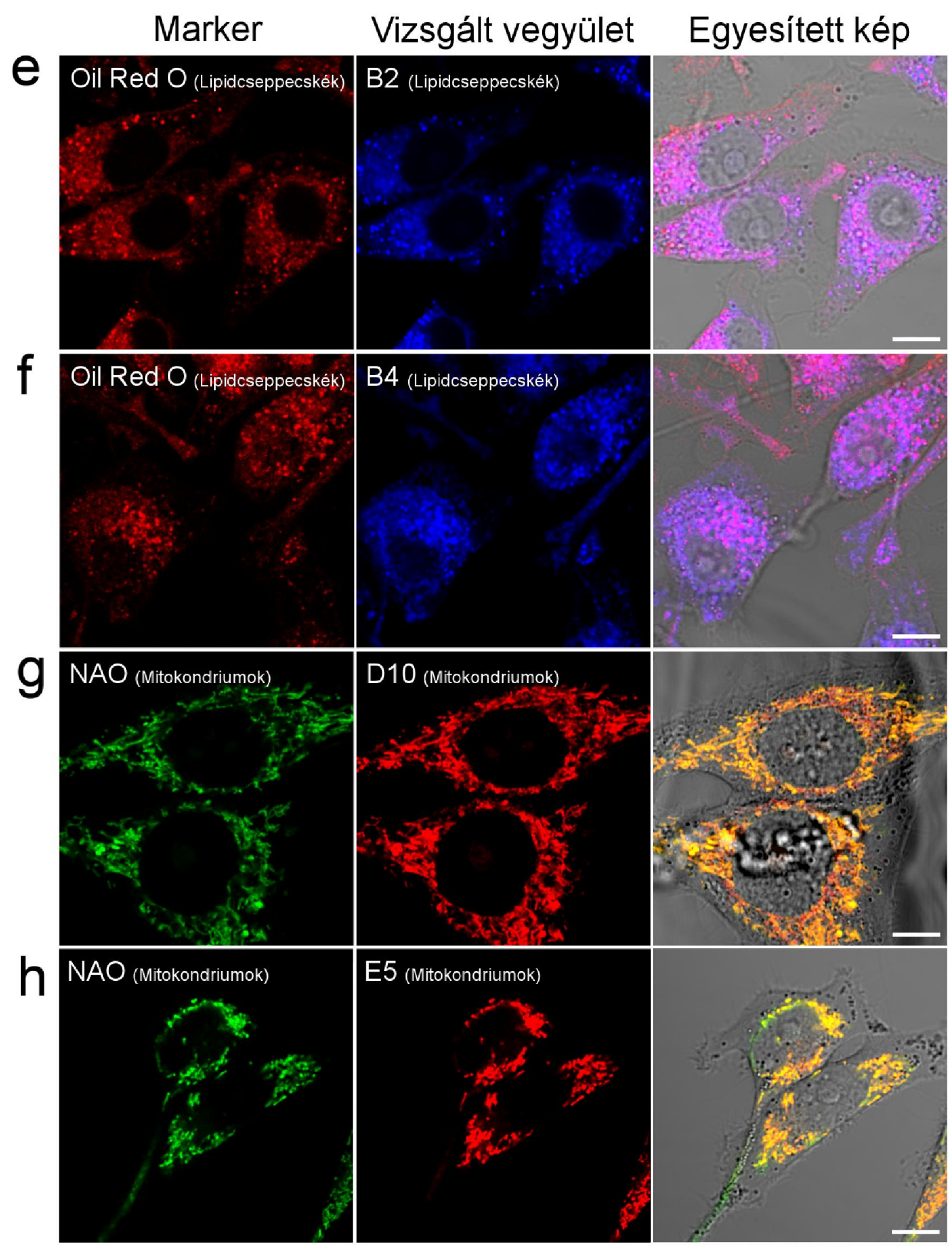

5/2. ábra. A vizsgált vegyületek kolokalizációja ismert markerekkel (második rész). A lokalizációt az ábrán feliratoztuk. Fixált (e-f) illetve élő sejteket (g-h) használtunk a vizsgálatokhoz. NAO: nonil-akridin-narancs. Skála: $10 \mu \mathrm{m}$. 


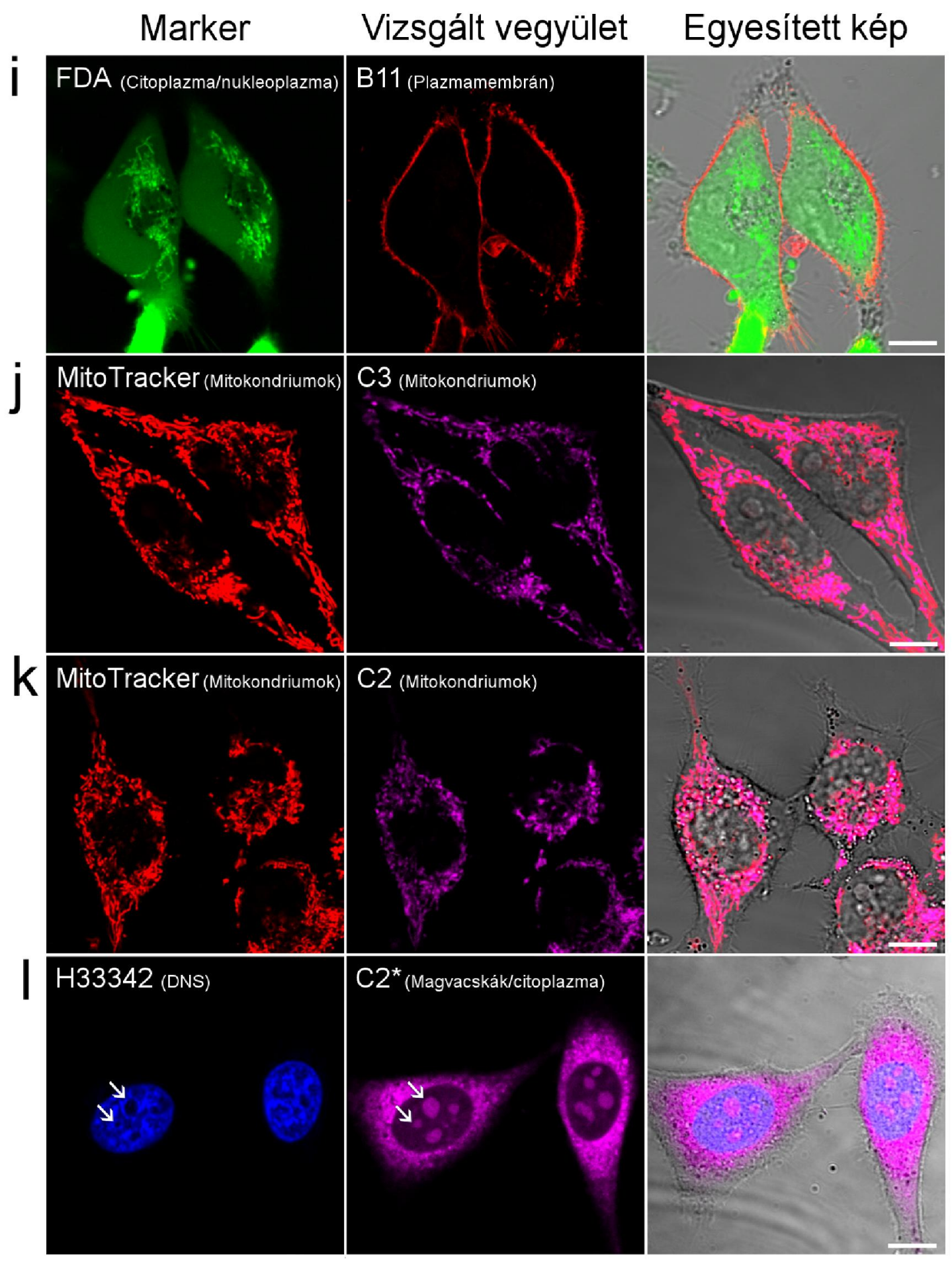

5/3. ábra. A vizsgált vegyületek kolokalizációja ismert markerekkel (harmadik rész). A lokalizációt az ábrán feliratoztuk. Élő sejteket használtunk a vizsgálatokhoz. FDA: fluoreszcein diacetát, H33342: Hoechst 33342, C2*: a C2 molekula fotokonvertált alakja. A nyilak két magvacskát mutatnak. Skála: $10 \mu \mathrm{m}$. 
A mikroszkópos analízis során a $\mathrm{C} 2$ vegyület szokatlan viselkedését figyeltük meg: a 633 nm-es lézerrel végzett 50\% intenzitású ismétlődő szkennelés a festékből származó jel fokozatos relokalizációját okozta a mitokondriumokból a citoplazmába illetve a magvacskába (5/3. ábra, $\mathbf{k}$ és $\mathbf{l})$. Ez a jelenség a fluoreszcens mikroszkóp rodamin filter beállításai (510-550 nm, zöld gerjesztés) mellett történő megvilágítással is indukálható volt. A C2* nukleoláris lokalizációjának alátámasztására élő sejteket egy órával a fotokonverzió után Hoechst 33342 DNS-festékkel festettünk, amely az RNS-gazdag magvacskákat negatívan jelöli (5/3. ábra I, nyilak). Úgy gondoljuk, hogy a fotokonvertibilis és fotoszenzitivizáló fluoreszcens fehérjékhez hasonlóan [67] a C2 vegyület is lézer-indukált szerkezeti változáson, fotokonverzión mehet át, amely relokalizációs viselkedéshez vezethet. Egy másik lehetőség, hogy a relokalizációt valójában a sejt károsodása okozza. Mivel a fluoreszcens próbák gyakran fotoszenzitivizáló hatással is rendelkeznek, a hosszabb megvilágítás letális fotodinamikai változásokhoz vezethet a fluoreszcens jel áttevődésével és a sejtmorfológia megváltozásával együtt [69]. A C2 vegyület fényindukált relokalizációja is hasonló fotoszenzitizáció és toxicitás eredménye lehet. A C2*-gal kezelt sejtek 1 napos inkubációt követő csökkent életképessége (6. ábra) is ezt a lehetőséget támasztja alá. Viszont a fotokonverzióhoz szükséges lézeres gerjesztés hiányában a C2 akár egy napon keresztül is stabilan a mitokondriumokban maradt. Kisebb intenzitású (4\%-os) 633 nm-es gerjesztés sem okozott fotokonverziót.

A molekuláknak a sejtek hosszútávú életképességére gyakorolt hatását is megvizsgáltuk. Pozitív kontrollként egy ismert apoptózis-indukáló szert, a 4hidroxitamoxifent (HT) alkalmaztuk $20 \mu \mathrm{M}$ koncentrációban. HeLa sejteket kezeltünk 24 órán keresztül $10 \mu \mathrm{M}$ koncentrációjú vegyületekkel (a $\mathrm{C} 2$ és a $\mathrm{C} 2 *$ molekulák koncentrációja $1 \mu \mathrm{M}$ volt). Az életképességet FDA-festéssel mértük, amely azon alapszik, hogy az élő sejtek észteráz aktivitásuk következtében a nem-fluoreszcens FDA-t zölden fluoreszkáló fluoreszceinné alakítják át [67]. A 6. ábrán látható, hogy a DMSO-kezelt sejtekkel összehasonlítva a 24 órás kezelés nem volt szignifikáns hatással az életképességre, kivéve a $\mathrm{C} 2 *$ és a HT vegyületeket. Így a festékek használhatók akár hosszútávú jelölési és követési kísérletekben is. Habár a $\mathrm{C} 2^{*}$ nem okozott semmilyen látható morfológiai változást a fotokonverziót követő egy órában (5/3. ábra I), a 24 órás kezelés a sejtek lekerekedéséhez és csökkent életképességéhez vezetett (a nyílhegyek a 6 . ábra $\mathrm{C} 2 *$ sorában halott sejteket 
jelölnek). Így azt a következtetést vontuk le, hogy a C2* felhasználhatósága rövid idejü (kb. 1 órás) kolokalizációs analízisekre korlátozódik.
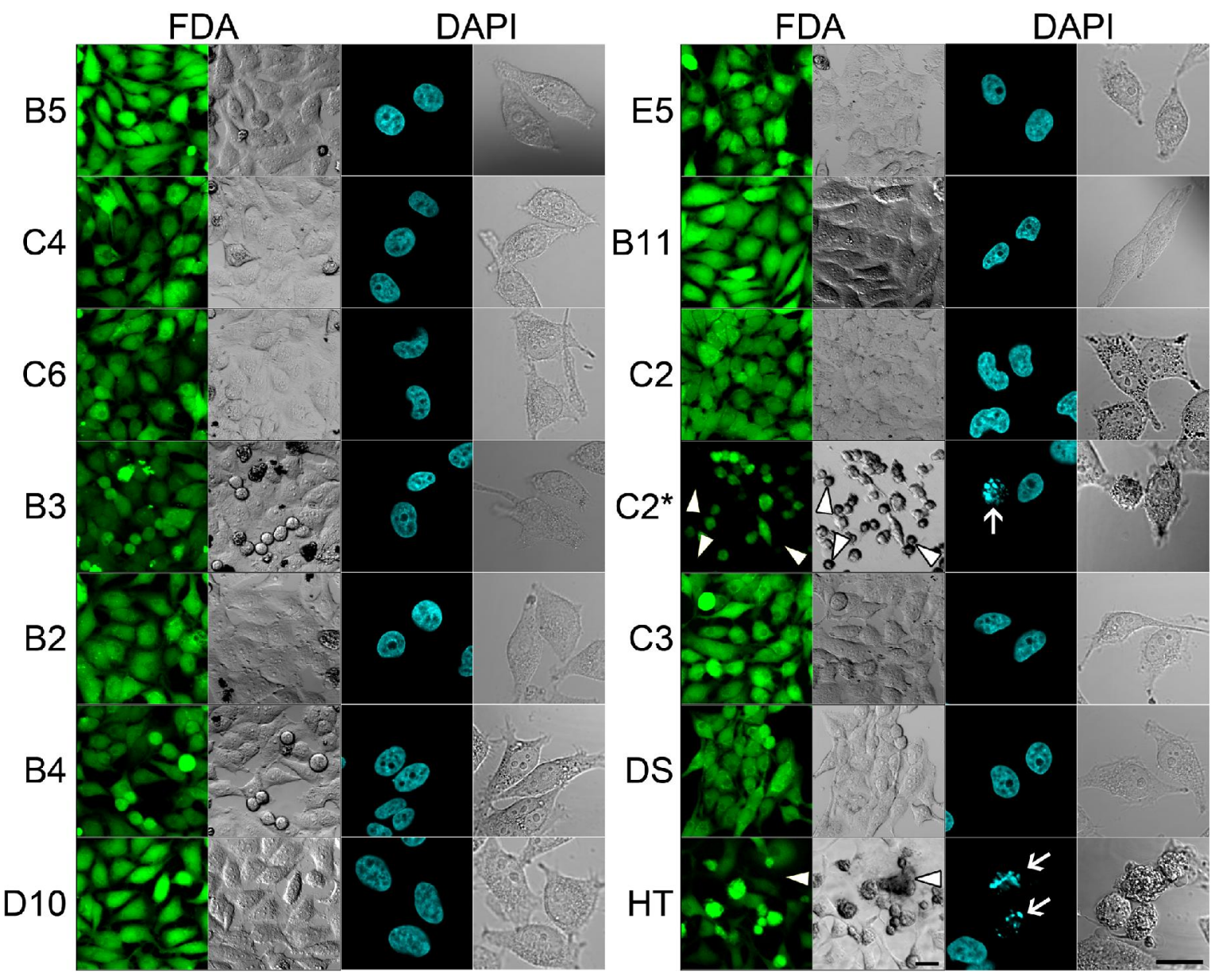

6. ábra. 24 órás kezelésnek alávetett HeLa sejtek életképességének és magmorfológiájának vizsgálata. FDA-val (zölden) jelzett élő sejteket és DAPI-val (kéken) festett fixált sejteket láthatunk a hozzájuk tartozó világos látóterü (feketefehér) képekkel. A C2* és a HT sorokban látható nyílhegyek FDA-negatív halott sejteket jeleznek, a nyilak pedig fragmentált, apoptotikus sejtmagokat jelölnek a C2* és a HT mintákban. C2*: a C2 molekula fotokonvertált alakja, DS: dimetil-szulfoxid, HT: 4-hidroxitamoxifen. A HT sorban láthatóak mind az FDA mind a DAPI képekhez tartozó $20 \mu \mathrm{m}$-es skálák.

Alternatív megközelítésként az apoptotikus sejtmagok megjelenését is vizsgáltuk. Az apoptotikus sejtek magjai határozott morfológiai változásokat mutatnak, mint a maghártya degradációja és membránhólyagok megjelenése [70]. A sejteket 24 órán át kezeltük $20 \mu \mathrm{M}$ 
HT-vel illetve $10 \mu \mathrm{M}$ koncentrációjú vegyületekkel ( $1 \mu \mathrm{M}$ C2-vel és C2*-gal), majd fixáltuk és DAPI-val megfestettük azokat, hogy láthatóvá tegyük a magok morfológiai változásait. Ahogy a 6. ábra mutatja, egyik molekula sem okozott ilyen változásokat a $\mathrm{C} 2 *$-ot és a HT-t kivéve, amelyeknél gyakran megfigyelhetőek voltak a hólyagok és a mikronukleuszok (6. ábra, C2* és HT sor DAPI-festés).

Az eredményeket összefoglalva elmondhatjuk, hogy a kismolekula microarray és a konfokális pásztázó mikroszkópia együttes alkalmazásával sikeresen azonosítottunk néhány egyedi, nem-toxikus, sejtpermeábilis (vagy plazmamembránhoz kötődő) fluoreszcens próbát. A molekulák kémiai módosításai és a jelölt célpontok részletes jellemzése révén a jövöben izgalmas lehetőségek kínálkoznak számos új, továbbfejleszett kémiai és spektrális tulajdonságokkal rendelkező flurofór felfedezésére. 


\subsection{Speciális felülethez kapcsolt kismolekulák alkalmazása affinitás kromatográfiában}

\subsubsection{AviLink felületmódosítással ellátott affinitás töltet előállítása és felhasználása célpontazonosításban}

Az új típusú affinitás töltet alkalmazhatóságát a tumorellenes hatóanyagfejlesztéseinkben szereplő trifluoro-amino-ftálimidek [68] egy újabb származékával, az Ac-2010 vegyülettel (7. ábra) kölcsönható fehérjék azonosításában mutattuk be.

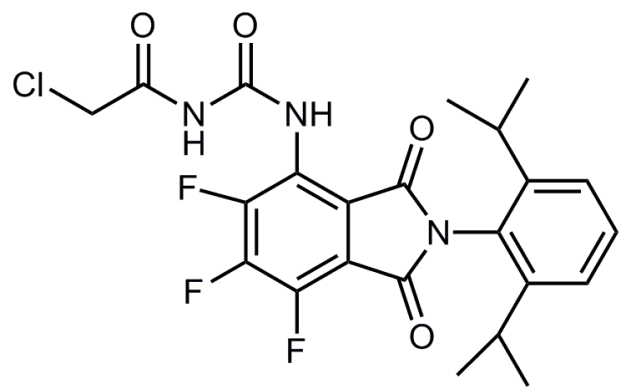

\section{7. ábra. Az Ac-2010 szerkezete.}

Az AviLink technológiával kezelt CPG-hez Ac-2010-et kapcsoltunk, majd az így elöállított affinitás töltetre patkány májból készített teljes fehérjekivonatot vittünk fel. A különböző affinitással kikötődött fehérjéket növekvő koncentrációjú sóoldattal, a szabad Ac2010 molekula feleslegben történő alkalmazásával, illetve detergenssel (SDS) eluáltuk a töltetröl. A kísérletet párhuzamosan egy „üres”, Ac-2010-et nem tartalmazó tölteten is elvégeztük. Az eluátumokat SDS-PAGE-vel analizáltuk. A specifikus sávokat (amelyek csak az Ac-2010 mintában voltak jelen, az „üres” kontrollban nem) a megfelelő kontrollokkal együtt kivágtuk a gélből és tömegspektrometriai elemzésnek vetettük alá. Az eredményeket a 2. táblázatban összegeztük. 


\begin{tabular}{|c|c|c|c|}
\hline Fehérje neve & $\begin{array}{r}\text { GI azonositó } \\
\text { szám }\end{array}$ & Peptidszám & $\begin{array}{r}\text { Szekvencia } \\
\text { lefedettség (\%) }\end{array}$ \\
\hline $\begin{array}{l}\text { Dimetilglicin dehidrogenáz, } \\
\text { mitokondriális }\end{array}$ & 2498527 & 32 & 49 \\
\hline Protein diszulfid izomeráz A4 & 149033487 & 25 & 37,5 \\
\hline Karboxilészteráz & 5732982 & 15 & 44,1 \\
\hline Kalretikulin prekurzor & 11693172 & 13 & 44 \\
\hline $\begin{array}{l}\text { Urokanáz domén tartalmú protein } 1 \\
\text { (prediktált) }\end{array}$ & 109472358 & 13 & 29,1 \\
\hline $\begin{array}{l}\text { Karbamoil-foszfát szintetáz } 1 \\
\text { prekurzor }\end{array}$ & 149016000 & 12 & 11,6 \\
\hline Proteaszóma béta 8 alegység & 258614012 & 10 & 26,1 \\
\hline Karboxilészteráz & 149032323 & 8 & 25,5 \\
\hline Proteaszóma béta 2 alegység & 8394079 & 4 & 21,9 \\
\hline Acilpeptid hidroláz & 149018550 & 4 & 12,7 \\
\hline Dipeptidil peptidáz III & 16758578 & 4 & 12,3 \\
\hline Kataláz & 6978607 & 4 & 11,4 \\
\hline Akonitát hidratáz-szerü fehérje & 149045627 & 4 & 9 \\
\hline Paratimozin & 14010875 & 3 & 17,6 \\
\hline Proteaszóma béta 5 alegység & 160333293 & 3 & 14,1 \\
\hline Transzferrin & 1854476 & 3 & 6,6 \\
\hline Proteaszóma béta 9 alegység & 258614009 & 2 & 15,1 \\
\hline Peroxiredoxin 1 & 16923958 & 2 & 14,1 \\
\hline X-prolil aminopeptidáz 1 & 149040371 & 2 & 8 \\
\hline Dihidropirimidináz & 13928984 & 2 & 6,4 \\
\hline Transzglutamináz 2, c polipeptid & 42476287 & 2 & 4,8 \\
\hline Protimozin alfa (prediktált) & 109477164 & 1 & 9,6 \\
\hline Proteaszóma béta 4 alegység & 149030731 & 1 & 8,3 \\
\hline Proteaszóma béta 6 alegység & 149053200 & 1 & 5,4 \\
\hline $\begin{array}{l}\text { Dihidrolipoamid dehidrogenáz } \\
\text { prekurzor }\end{array}$ & 40786469 & 1 & 3,7 \\
\hline Máj karboxilészteráz N & 134034200 & 1 & 2,5 \\
\hline Béta-glükuronidáz & 114965 & 1 & 2,3 \\
\hline $\begin{array}{l}\text { Karboxilészteráz } 1 \text { c izoforma } \\
\text { prekurzor (prediktált) }\end{array}$ & 109507790 & 1 & 2,2 \\
\hline Transzferrin & 149018747 & 1 & 2 \\
\hline Szérum albumin & 124028612 & 1 & 2 \\
\hline
\end{tabular}

2. táblázat. Az Ac-2010-hez kötődő fehérjék. Az Ac-2010 kismolekulát AviLink felülettel ellátott CPG-hez kapcsoltuk, majd az így előálított tölteten patkány máj teljes fehérjekivonatát engedtünk át. A kikötődött fehérjéket SDS-PAGE és tömegspektrometria segítségével azonosítottuk. 
Az egyik fehérje, név szerint a protein diszulfid izomeráz (PDI) (2. táblázat 2. sora), több okból is felkeltette az érdeklődésünket: egyrészt ez egy meglehetősen nagy peptidszámmal (25) és szekvencia lefedettséggel (37.5\%) rendelkező találat volt, másrészt korábbi, más trifluoro-amino-ftálimidekkel végzett affinitás kromatográfiás kísérletek eredményei között is többször találkoztunk ezzel a fehérjével. Ráadásul az irodalmi adatok szerint a PDI az ER mellett [71] a lipidcseppecskékhez asszociáltan is előfordulhat [72], és az Ac-vegyületekröl kimutattuk, hogy szintén ezekkel a sejtalkotókkal mutatnak kolokalizációt (5/1. ábra d, 5/2. ábra e-f és [68]). Ezen kívül azt is tudjuk, hogy a PDI katalizálja a kiválasztásra kerülő fehérjékben helytelenül kialakult diszulfid-hidak újrarendeződését [71], így a PDI aktivitás elvesztése a rosszul tekeredett fehérjék ER-beli felhalmozódását, ezáltal ER-stresszt, majd sejthalált okozhat. Az általunk szintetizált trifluoro-amino-ftálimid származékok lehetséges hatásmechanizmusaként pedig éppen az ER-stressz kiváltását vázoltuk fel [68]. Mindezen ismeretek fényében úgy döntöttünk, hogy megvizsgáljuk az Ac-2010 vegyületnek a PDI enzimaktivitására gyakorolt hatását, és így megpróbáljuk alátámasztani az affinitás kromatográfiával kapott eredményt. Ezért inzulinturbidimetriás mérésekkel többféle koncentrációban teszteltük az Ac-2010-et, és úgy találtuk, hogy az már $1 \mu \mathrm{M}$ koncentrációban gátolta az inzulin PDI-függő redukcióját (8. ábra), az $\mathrm{IC}_{50}$ értéke pedig $3.158 \mu \mathrm{M}$ volt. 


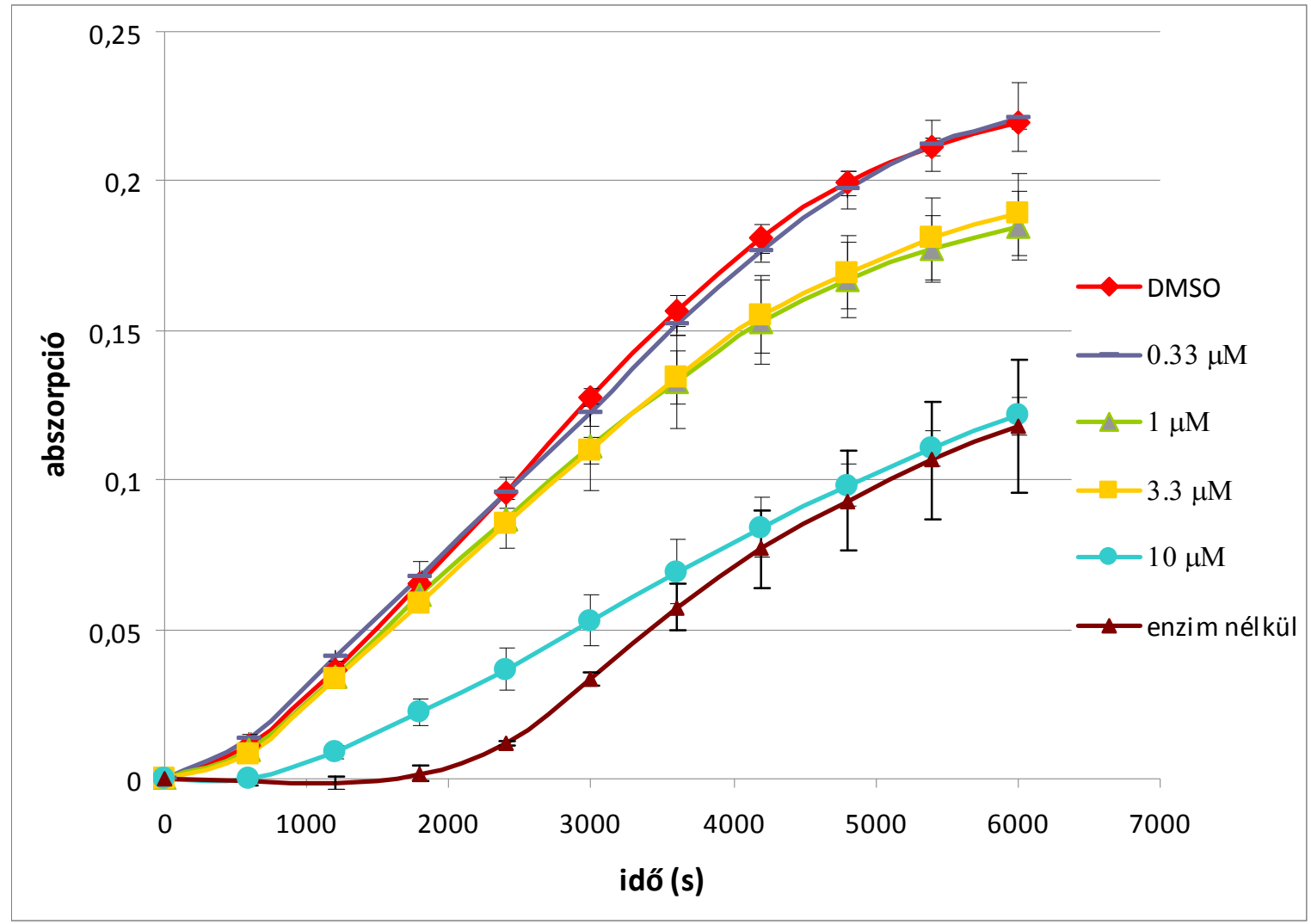

8. ábra. Az Ac-2010 hatása a PDI enzimaktivitására. Különböző koncentrációjú (0.33, 1, 3.3 és $10 \mu M)$ Ac-2010-et adtunk az enzimreakciókhoz. A reakciók lefolyását a 340 nm-hez tartozó abszorpció mérésével követtük. A kontroll reakciókhoz („DMSO” és „enzim nélkül””) az Ac-2010 helyett 1-1 $\mu$ l DMSO-t adtunk. Az ,enzim nélkül” kontrollból kihagytuk a PDI-t. Az ábra három párhuzamos mérés átlagait és szórásait mutatja.

Tehát az affinitás kromatográfiával eredményül kapott lehetséges kölcsönható fehérjék közül a PDI-ről sikerült kimutatnunk, hogy valóban kötődik az Ac-2010 molekulához, sőt ez a kötődés az enzim aktivitását is befolyásolja. Megállapíthatjuk tehát, hogy az AviLink technológiával lehetséges a gyógyszerjelölt kismolekulákkal-kapcsolt affinitás töltetek létrehozása, és az így elöállított töltetek alkalmasak az adott kismolekulákkal kölcsönható fehérjék azonosítására. 


\subsubsection{Nem-specifikusan kötődő fehérjék eltávolítása sejt- és szövetkivonatokból}

\section{2-aminobenzimidazollal kapcsolt affinitás töltettel}

Az előtisztító affinitás-felület alapjául szolgáló CPG-t szilanizáltuk, azaz Si atom tartalmú, reaktív oldalláncokat kapcsoltunk hozzá (9. ábra, A). A szilanizált felület lehetővé tette, hogy molekuláris távtartó kart építsünk be a 2-aminobenzimidazol csoport elé, amely csoport az affinitás töltetekhez nem-specifikusan kötődő tubulin kihalászásáért felelös. Tapasztalatunk szerint leginkább az izoftálsav felel meg molekuláris távtartóként, amelyet izoftálsav-diklorid alkalmazásával építettünk be a készülő affinitás-felületre (11. ábra, B). A molekuláris távtartó kar több célt szolgált. Egyrészt kémiailag stabilan kapcsolhattuk hozzá a tubulin kikötésében közvetlen szerepet játszó 2-aminobenzimidazolt (11. ábra, C), másrészt megfelelő távolságot tartott az üvegfelület és a 2-aminobenzimidazol között. Erre a megfelelő távolságra azért volt szükség, hogy a fehérjének legyen elegendő helye a stabil kötődéshez, illetve a 2-aminobenzimidazol csoportnak legyen elegendő mozgástere saját molekuláris környezetében az optimális kötéserősség kialakításához.
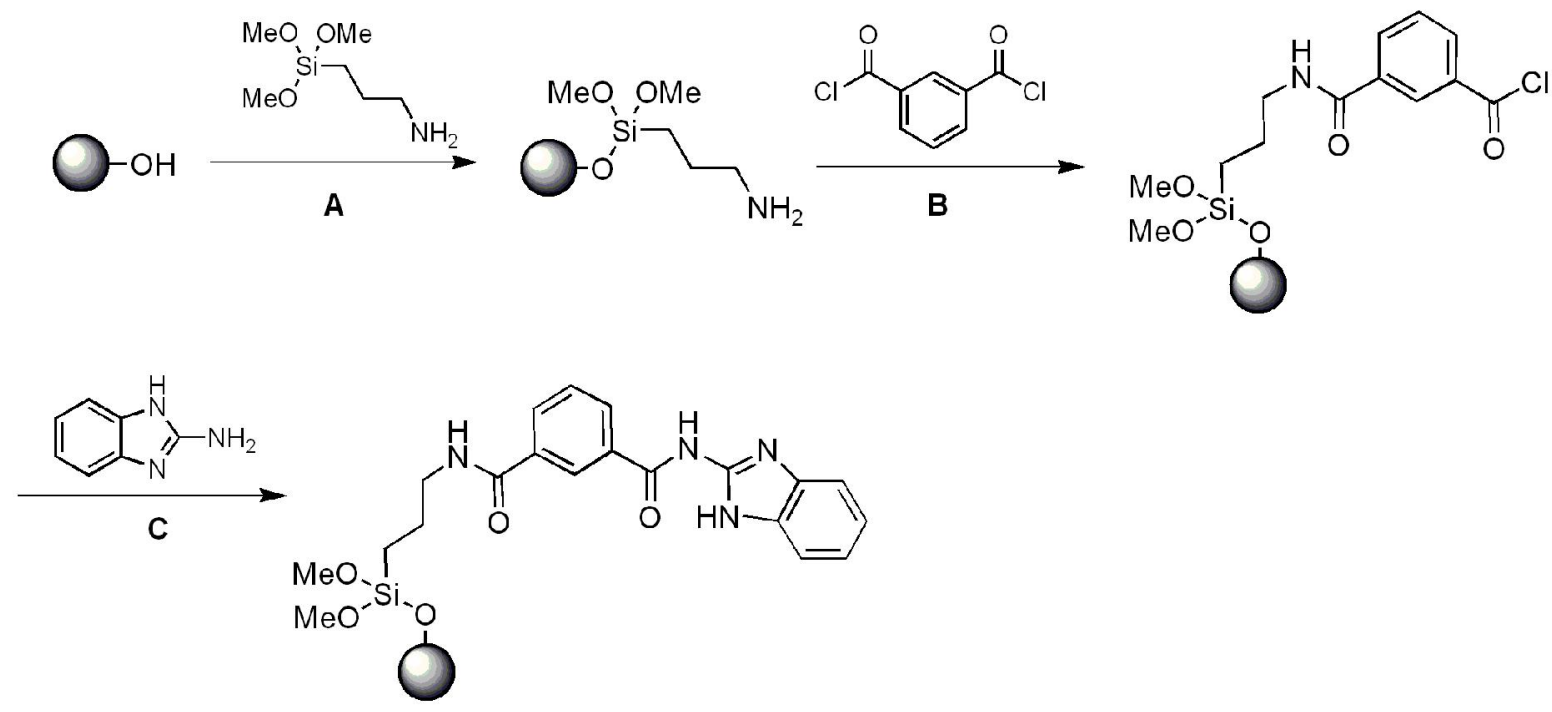

9. ábra. A 2-aminobenzimidazollal-kapcsolt affinitás-felület előállítása három lépésben. A CPG részecskéket 3-aminopropil-trimetoxiszilánnal kezeltük (A), majd izoftálsavdikloridon keresztül (B) 2-aminobenzimidazolt kapcsoltunk (C) a szilanizált CPG-hez. 
A 2-aminobenzimidazollal kapcsolt CPG felületi lefedettségét az affinitás töltet előállításának lépéseiben keletkezett termékek elemanalizátorral mért széntartalmából a kiterjesztett Berendsen-de Galan egyenletek [66] alapján számítottuk ki:

$$
\begin{aligned}
& \alpha_{1}=\frac{10^{6} p_{1}}{S_{0}\left(100 C n_{1}-p_{1} M_{1}\right)} \\
& \alpha_{2}=\frac{10^{8} C n_{1}\left(p_{2}-p_{1}\right)}{S_{0}\left(100 C n_{1}-p_{1} M_{1}\right)\left(100 C n_{2}-p_{2} M_{2}\right)} \\
& \alpha_{3}=\frac{10^{8} C n_{1}\left(100 C n_{2}-p_{1} M_{2}\right)\left(p_{3}-p_{2}\right)}{S_{0}\left(100 C n_{1}-p_{1} M_{1}\right)\left(100 C n_{2}-p_{2} M_{2}\right)\left(100 C n_{3}-p_{3} M_{3}\right)}
\end{aligned}
$$

Az alsó indexben szereplő számok az egyes kikötött csoportokat (1: 3-aminopropiltrimetoxiszilán maradék, 2: izoftálsav-klorid csoport, 3: 2-aminobenzimidazol csoport) jelölik. $\alpha$ a kikötött csoport felületi lefedettsége, $p$ a széntartalom $\mathrm{m} / \mathrm{m} \%$-ban, $S_{0}$ a natív CPG specifikus felülete $\left(51 \mathrm{~m}^{2} / \mathrm{g}\right), C$ a szén atomtömege, $n$ a kikötött csoportban lévő szénatomok száma, $M$ a kikötött csoport molekulatömege $\left(M_{1}=164.29 \mathrm{~g} / \mathrm{mol}, M_{2}=167.57\right.$ $\left.\mathrm{g} / \mathrm{mol}, M_{3}=132.15 \mathrm{~g} / \mathrm{mol}\right)$. A $p, n$ és $\alpha$ értékeit a 3. táblázat tartalmazza.

A kapott eredmények alapján az amino-szilanizált CPG részecskék aktív csoportjainak feléhez $\left(0.33 \mu \mathrm{mol} / \mathrm{m}^{2}\right)$ sikerült közvetetten 2-aminobenzimidazol molekulát kapcsolni (3. táblázat). A 2-aminobenzimidazollal nem fedett aktivált csoportokat 5\% etanolaminnal semlegesítettük.

\begin{tabular}{|lrrr|}
\hline Termék & $\boldsymbol{p}(\boldsymbol{m} / \boldsymbol{m} \boldsymbol{\%})$ & $\boldsymbol{n}$ & $\alpha\left(\boldsymbol{\mu m o l} / \mathbf{m}^{2}\right)$ \\
\hline (A) Amino-szilanizált CPG & 0.20 & 5 & 0.66 \\
(B) Izoftál-CPG & 0.45 & 8 & 0.52 \\
(C) 2-aminobenzimidazol-CPG & 0.59 & 7 & 0.33 \\
\hline
\end{tabular}

3. táblázat. A 2-aminobenzimidazollal kapcsolt affinitás töltet előállítása során keletkezett reakciótermékek széntartalma és számított felületi lefedettsége. Az egyes termékek neve előtti betű mutatja, hogy a 9. ábrán látható reakciók közül melyiknek a termékéről van szó, illetve hogy melyik egyenlet alapján számítottuk ki $\alpha$-t. $p$ : széntartalom, $n$ : szénatomok száma a kikötött csoportban, $\alpha$ : felületi lefedettség. 
A töltet hatékonyságát humán A549 sejtből illetve patkány agyból nyert teljes fehérjekivonat depletálásával mutattuk be. A fehérjekivonatokat a 2-aminobenzimidazollal kapcsolt töltetre vittük. A töltetről a gyengén kötődő fehérjéket lemostuk, majd a mosóoldatokat az átfolyóval egyesítettük. A kiindulási minta és az átfolyó frakció fehérjeprofilját kétdimenziós gélelektroforézissel hasonlítottuk össze (10. ábra). A gélek szoftveres analízisét követően kivágtuk és tömegspektrometriai módszerekkel azonosítottuk azokat a fehérjefoltokat, amelyek nem voltak jelen, vagy sokkal gyengébbek voltak az átfolyó frakció géljén, mint a kiindulási mintáén.

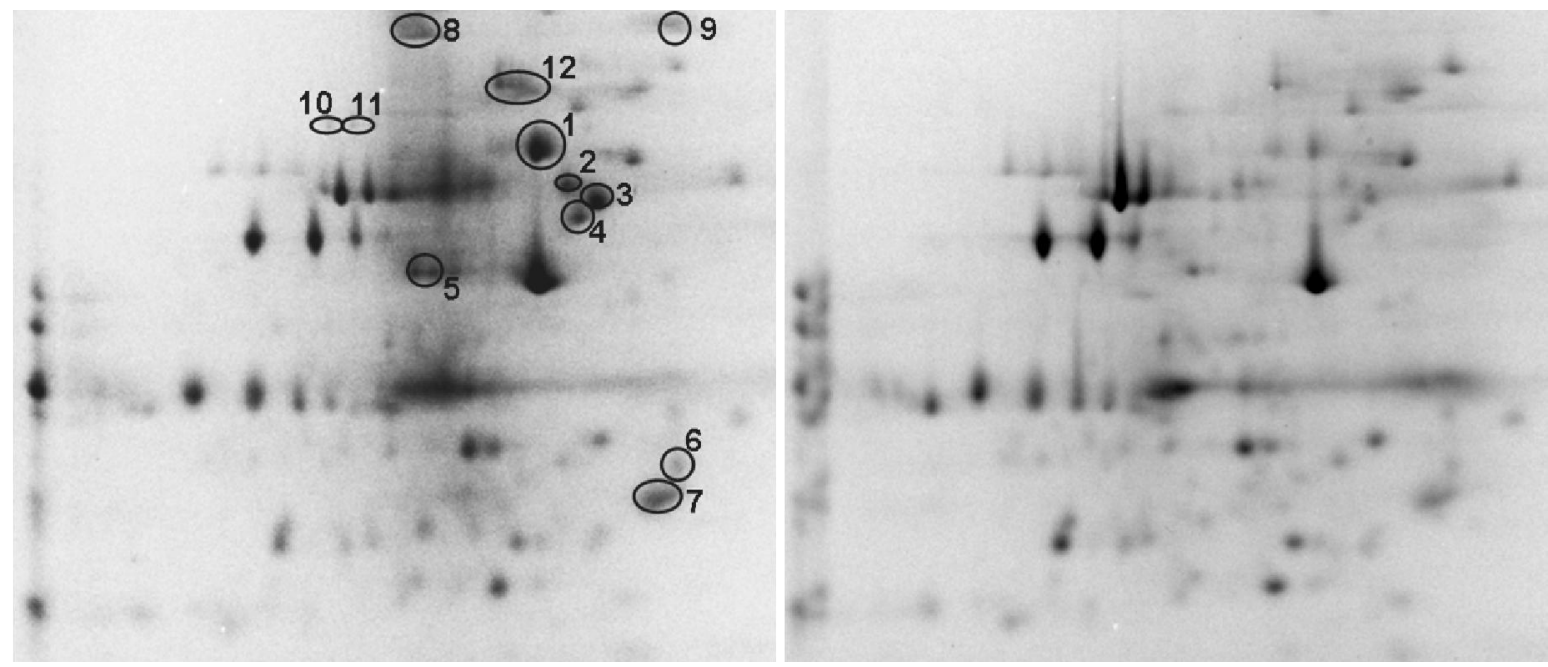

10. ábra. 2-aminobenzimidazollal-kapcsolt töltettel nem-depletált (A) és depletált (B) A549 sejtkivonat kétdimenziós gélképe. A karikák azokat a fehérjefoltokat jelölik, amelyek hiányoznak vagy sokkal gyengébbek a depletált mintában, tartalmukat tömegspektrometriai módszerekkel azonosítottuk (a számok a 4. táblázat első oszlopában szereplő számoknak felelnek meg).

12 foltból 20 különböző fehérjét azonosítottunk a humán sejt minta esetében (4. táblázat). A tubulinok mellett főként más citoszkeletális komponensek (aktinok), a 14-3-3 fehérjecsalád tagjai és hősokkfehérjék kötődtek a töltethez. A patkány agy mintához tartozó gélből 14 foltot vágtunk ki és vetettünk alá tömegspektrometriai elemzésnek (5. táblázat). A 16 azonosított fehérje nagy része megfelel a humán sejt mintából azonosított fehérjéknek. 


\begin{tabular}{|rlr|}
\hline No. & Fehérje neve & GI azonosító \\
Szám \\
\hline 1 & Chaperonin & 31542947 \\
1 & Béta-aktin & 4501885 \\
2 & Alfa-tubulin & 32015 \\
\hline 3 & Béta-tubulin & 338695 \\
\hline 3 & Mitokondriális ATP szintáz & 89574029 \\
\hline 4 & Mitokondriális ATP szintáz & 89574029 \\
\hline 4 & Protein diszulfid izomerázzal rokon protein 5 & 1710248 \\
\hline 5 & Béta-aktin & 4501885 \\
\hline 6 & $14-3-3$ protein epszilon & 5803225 \\
\hline 6 & $14-3-3$ protein zéta/delta & 4507953 \\
\hline 6 & $14-3-3$ protein théta & 5803227 \\
\hline 7 & $14-3-3$ protein zéta/delta & 4507953 \\
\hline 7 & $14-3-3$ protein théta & 5803227 \\
\hline 7 & $14-3-3$ protein gamma & 9507245 \\
\hline 8 & Hsp90 alfa 2 & 61656603 \\
\hline 9 & Hsp90 béta 1 & 4507677 \\
\hline 10 & Stressz-indukált-foszfoprotein 1 (hsp70/hsp90-szervező fehérje) & 5803181 \\
\hline 11 & Aldehid dehidrogenáz 1A1 & 21361176 \\
11 & Stressz-indukált-foszfoprotein 1 (hsp70/hsp90-szervező fehérje) & 5803181 \\
\hline 12 & 70 kDa-os hösokkfehérje 9 & 12653415 \\
12 & Hsp70-2 & 4529892 \\
12 & 70 kDa-os hősokkfehérje 8, 1-es izoforma & 5729877 \\
12 & Hősokk-indukált fehérje & 188492 \\
12 & 60 kDa-os hösokkfehérje & 77702086 \\
12 & Aktin, gamma 1 propeptid & 4501887 \\
12 & Chaperonin & 31542947 \\
\hline
\end{tabular}

4. táblázat. A humán sejtminta depletált fehérjéi. Az első oszlopban található számok a 10. ábrán látható számoknak felelnek meg. 


\begin{tabular}{|lr|}
\hline Fehérje neve & GI azonosító szám \\
\hline 70kDa-os hösokkfehérje 5(grp78) & 25742763 \\
\hline Hősokkfehérje 8 & 13242237 \\
Chaperonin 60 & 1778213 \\
ATP szintáz, H+ transzportáló, mitokondriális F1 komplex, béta & 54792127 \\
alegység & 1374715 \\
ATP szintáz béta alegység & 109507063 \\
Aktin, citoplazmatikus 2 (gamma-aktin) & 119959830 \\
Béta-aktin & 984553 \\
G-fehérje béta 1 alegység & 71089939 \\
Guanin nukleotid kötő fehérje béta 2 & 1051270 \\
\hline 14-3-3 zéta & 6981710 \\
\hline 14-3-3 éta & 9507245 \\
14-3-3 gamma & 40254595 \\
\hline Dihidropirimidináz-szerü fehérje 2 & 203055 \\
\hline ATP szintáz alfa alegység prekurzor & 40538742 \\
ATP szintáz, H+ transzportáló, mitokondriális F1 komplex, alfa & 8393418 \\
\hline alegység, 1-es izoforma
\end{tabular}

\section{5. táblázat A patkány agy minta depletált fehérjéi.}

Egyes azonosított fehérjékről már korábban leírták, hogy kötődnek a tubulinhoz, ezek a hsp70 [73, 74], a hsp90 [74, 75], a hsp70/hsp90-szervező fehérje, a grp78 [74], a GAPDH [76], a 14-3-3 fehérjék [77] és a G-proteinek [78]. A többi fehérje esetében ilyen irodalmi adatokat nem találtunk, ezeknél a mátrixszal való kölcsönhatás természete nem ismert.

Mindkét mintánál megfigyelhető volt, hogy az átfolyó frakció géljén az azonosított foltok száma és több folt intenzitása is megnövekedett (összesen 21 darabé a sejt- és 20 darabé az agymintában) a kiindulási minta géljéhez képest. Ezeknek az új, vagy intenzívebb foltoknak a megjelenése - amit néhány nem-specifikusan kötődő fehérje depléciójának tulajdonítunk - azt jelentheti, hogy több kis mennyiségben jelenlévő fehérjét detektálunk, mint a nem-depletált mintában.

Tehát az általunk előállított 2-aminobenzimidazollal kapcsolt előtisztító töltet ígéretesnek bizonyult nyers sejt- vagy szövetmintákon való alkalmazásban és megkönnyítheti az intracelluláris gyógyszercélpontok azonosítását. 


\section{5. Összefoglalás}

A néhány száz Dalton tömegủ szerves vegyületek, más néven kismolekulák amellett, hogy az élő sejtek alapvető alkotóelemei közé tartoznak - a gyakorlatban elsősorban gyógyszerekként és a molekuláris biológia eszközeiként ismertek. A dolgozat kismolekulákon alapuló módszertani fejlesztéseket mutat be.

\subsection{Kismolekula microarray és konfokális pásztázó mikroszkópia együttes alkalmazása élő sejteket festő fluoreszcens markerek azonosítására}

A fluoreszcencia jelenségét, vagyis azt, hogy bizonyos molekulák elektromágneses sugárzás hatására a gerjesztés ideje alatt fényt bocsátanak ki, számos tudományterület mellett a biológia és az orvostudomány is hasznosítja sejtek, sejtalkotók vagy egyes molekulák jelölésében. Erre a célra leggyakrabban fluoreszcens fehérjéket és kismolekula festékeket alkalmaznak. A fluoreszcens fehérjék, mint pl. a GFP és származékai széles körben használatosak a vizsgált géntermékkel alkotott fúziós fehérje formájában, mivel lehetővé teszik a sejtes folyamatok dinamikájának elemzését és a biomolekulák kölcsönhatásainak vizsgálatát. Azonban a fluoreszcens fehérjék nem szorították ki a régóta alkalmazott kismolekula festékeket köszönhetően az utóbbiak olyan előnyös tulajdonságainak, mint a nagy membránpermeabilitás, az alacsony toxicitás, a minimális technikai korlátok és az alacsony költségek.

Habár fluorokrómok százait fedezték már fel és alkalmazták képalkotó eljárásokban, továbbra is van igény az új célpontokat jelölő vagy különleges spektrális tulajdonságokkal rendelkező új molekulák iránt. Jelenleg a racionális tervezési és a HTS technikák jelentik az új festékek két fő forrását. A HTS módszerek viszonylag olcsó, gyors és automatizálható lehetőséget nyújtanak új fluoreszcens próbák azonosítására akár előzetes szerkezeti ismeretek nélkül is. Az ezredforduló óta a kismolekula microarray-ekkel gyarapodott a HTS módszerek tárháza: üvegfelületen rögzített vegyületek tízezrei közül történhet egy vizsgált fehérjéhez (célponthoz) specifikusan kötődő hitmolekulák kiszürése. Mivel a kölcsönhatás kimutatása a fehérje fluoreszcens jelölésén alapul, a natív fluorokrómokat célszerü kizárni ezekből a vizsgálatokból. Viszont az ilyen molekulák között új fluoreszcens próbákat 
fedezhetünk fel. Így a kismolekula microarray technikát konfokális pásztázó mikroszkópiával kombinálva új fluoreszcens festékeket kerestünk több ezer molekula között.

Először 14585 különböző vegyületet rögzítettünk microarray formátumban, majd lézerszkenner segítségével detektáltuk a lenyomtatott molekulákból származó fluoreszcens jeleket. Az adatok szoftveres analízise során kiválasztottunk 278 db erős fluoreszcenciát mutató kismolekulát, majd ezeket élő sejteken tanulmányoztuk konfokális mikroszkóppal. $\mathrm{Az}$ impermeábilis, toxikus, rosszul oldódó vagy a sejtekben gyengén emittáló jelöltek kiejtése után a megmaradt 11 potenciális fluoreszcens festéket vizsgáltuk tovább.

Ismert fluoreszcens markerek segítségével megállapítottuk a fluorokrómok intracelluláris lokalizációját: a vizsgált vegyületek a lipidcseppecskékkel, a mitokondriumokkal, a plazmamembránnal és a sejtmag körüli régióval asszociálódtak. Öt lipidcseppecskét festő molekulánk mindegyike alkalmasnak bizonyult ezen sejtszervecskék in vivo jelölésére, szemben a rutinszerúen használt Oil Red O markerrel, amely a sejtek fixálását igényli. A B11 molekula a plazmamembránt festette, és fluoreszcenciája még egynapos inkubáció után is látható maradt a sejtek életképességének rontása nélkül, így használható lehet hosszútávú kísérletekben is. A C2 vegyület ismételt lézeres gerjesztés hatására szokatlan viselkedést mutatott: a fluorokrómból származó jel a mitokondriumokból a citoplazmába illetve a magvacskákba tevődött át.

A 11 molekulának a sejtek hosszútávú életképességére gyakorolt hatását FDAfestéssel és apoptózis markerek keresésével is vizsgáltuk. A 24 órás kezelés alatt - a C2 vegyület fotokonvertált alakját leszámítva - egyik általunk felfedezett fluoreszcens festék sem bizonyult toxikusnak, így ezek akár hosszabb kísérletekben is használhatók lehetnek.

Elmondhatjuk tehát, hogy a két módszer kombinálása alkalmas stratégiának bizonyult új, in vivo körülmények között alkalmazható fluoreszcens próbák felfedezésére. 


\subsection{Speciális felülethez kapcsolt kismolekulák alkalmazása affinitás kromatográfiában}

\subsubsection{AviLink felületmódosítással ellátott affinitás töltet előállítása és felhasználása célpontazonosításban}

A gyógyszerfejlesztés fontos lépése a gyógyszerjelölt molekula célpontjának/célpontjainak azonosítása, és ezáltal hatásmechanizmusának és lehetséges mellékhatásainak felderítése. Affinitás kromatográfiával mindezen fehérjék meghatározhatók: a hordozóra rögzített gyógyszerjelölt molekula kifogja egy keverékből a hozzá kötődő fehérjéket, miközben a keverék a hordozón átfolyik.

A ligand szilárd hordozón való rögzítése hasonló problémákat (szintézis szükségessége, a kikötött molekula nem megfelelő orientációja) vet fel a kismolekula microarray és a célpontazonosításban használt affinitás töltet esetében is, így az utóbbinál is felmerül megoldásként az AviLink felületmódosítási technológia bevetése. Ennek az új típusú affinitás töltetnek az alkalmazhatóságát egy általunk szintetizált trifluoro-aminoftálimiddel, az Ac-2010 vegyülettel kölcsönható fehérjék azonosításában próbáltuk ki.

Az AviLink technológiával elő́llított Ac-2010 affinitás töltetre patkány máj teljes fehérjekivonatát vittük fel. A kikötődött fehérjéket eluáltuk a töltetről, majd azokat a párhuzamos kontroll mintákkal együtt SDS-PAGE-vel analizáltuk. A töltethez specifikusan kötődő fehérjéket tömegspektrometriával határoztuk meg. A kromatográfiás eredmények, a trifluoro-amino-ftálimid származékok intracelluláris lokalizációja és feltételezett hatásmechanizmusa alapján úgy döntöttük, hogy a kapott 30 fehérjetalálat egyikét, a PDI-t megvizsgáljuk abból a szempontból, hogy az Ac-2010 hatással van-e az enzimatikus aktivitására. Inzulin-turbidimetriával teszteltük az Ac-2010-et, és úgy találtuk, hogy az már 1 $\mu \mathrm{M}$ koncentrációban gátolta az enzim müködését, az $\mathrm{IC}_{50}$ értéke pedig $3.158 \mu \mathrm{M}$ volt.

Tehát az affinitás kromatográfiával kapott lehetséges kölcsönható fehérjék közül a PDI-ről kimutattuk, hogy nemcsak köt az Ac-2010 molekulához, de a kötődés az enzim aktivitására is hatással van. Megállapíthatjuk tehát, hogy az AviLink technológia alkalmas kismolekula affinitás töltetek létrehozása, és az így elöállított töltetek révén az adott kismolekulával kölcsönható fehérjék azonosítására. 


\subsubsection{Nem-specifikusan kötődő fehérjék eltávolítása sejt- és szövetkivonatokból 2-aminobenzimidazollal kapcsolt affinitás töltettel}

Összetett mintákban a kis mennyiségben jelenlévő célpontok azonosítását különösen megnehezíti az abundáns fehérjék nem-specifikus kötődése a kismolekulát hordozó töltethez. A probléma megoldására változatos módszerek születtek, mint a kompetitív elúció, az aktív és inaktív ligand párhuzamos alkalmazása, a sorozatos affinitás kromatográfia, felületmódosítások, molekuláris távtartó kar beépítése, vagy a plazma proteomikai tanulmányokból ismert immunaffinitáson alapuló depléciós oszlopok.

Elhatároztuk, hogy egy olyan depléciós töltetet hozunk létre, amelyhez specifikus antitestek helyett egy kismolekulát, 2-aminobenzimidazolt kapcsolunk. A benzimidazol ugyanis kötődik a sejtekben nagy mennyiségben jelenlévő tubulinhoz, amely hajlamos rá, hogy nem-specifikusan „kiragadjon” az affinitás oszlopokon. Az előtisztító töltet alapjául szilanizált, reaktív oldalláncokat hordozó CPG-t állítottunk elő, amelyre molekuláris távtartó karként izoftálsavat építettünk be a benzimidazol csoport elé. Az egyes lépések reakciótermékeinek széntartalmát elemezve arra a következtetésre jutottunk, hogy a szilanizált CPG részecskék aktív csoportjainak feléhez sikerült 2-aminobenzimidazol molekulát kapcsolnunk.

A töltet hatékonyságát humán A549 sejtből illetve patkányagyból kivont teljes fehérjeminták depletálásával demonstráltuk. Kétdimenziós gélelektroforézist követően kivágtuk és tömegspektrometriai módszerekkel azonosítottuk azokat a fehérjéket (20-at az A549 sejt- és 16-ot az agymintából), amelyek a tölteten megkötődtek: föként citoszkeletális komponenseket (tubulinokat és aktinokat), a 14-3-3 fehérjecsalád tagjait és hősokkfehérjéket találtunk. Az azonosított fehérjék egy része feltehetőleg koprecipitálódott a tubulinnal, más fehérjék esetében a mátrixszal való kölcsönhatás természete nem ismert. Mindkét mintánál megfigyelhető volt, hogy az elötisztítás utáni átfolyóban új fehérjék jelentek meg, illetve egyes fehérjék mennyisége megnőtt, amit a nem-specifikus fehérjék depléciójának tulajdonítunk. Így azt feltételezzük, hogy a 2-aminobenzimidazollal kapcsolt előtisztító töltet nyers sejt- vagy szövetmintákon való alkalmazása megkönnyítheti az intracelluláris gyógyszercélpontok azonosítását. 


\section{Summary}

Low molecular weight (some hundred Daltons) organic compounds, i. e. small molecules serve as basic elements of the living cells and in practice they are known as drugs and molecular biology tools. We present here small molecule-based methodical developments.

\subsection{Combination of small molecule microarray and confocal microscopy techniques for live cell staining fluorescent dye discovery}

Fluorescence, namely that certain molecules emit light when excited with electromagnetic radiation, is utilized by several disciplines including biology and medicine, which apply it in the labelling of cells, cellular compartments or single molecules. Generally, fluorescent proteins and small molecule dyes are used for this purpose. Fluorescent proteins, like GFP and its derivatives are widely used in a fused form with the protein of interest, because they enable us to analyze the dynamics of the cellular processes and establish the interactions of biomolecules. However, small molecule dyes are not eliminated by fluorescent proteins due to their advantageous properties like high membrane permeability, less or no toxicity, minimal technical limitations and moderate cost.

Although several fluorochromes are discovered and applied in imaging studies so far, there is still a demand for novel molecules marking new targets or having improved spectral characteristics. Currently rational design and HTS techniques are the main sources of novel dyes. HTS methods provide a relatively inexpensive, rapid and easy to automate way to identify novel fluorescent probes even without any structural precognitions. At the beginning of the millennium the scope of HTS methods was broadened with small molecule microarrays. Since then tens of thousands of compounds immobilized on a glass surface can be screened for hits that specifically bind the target protein. Since detection of the interaction is based on the fluorescent labelling of a protein, small molecules showing native fluorescence ought to be excluded from these studies, but they still have the potential to be used as fluorescent probes. 
Therefore we decided to combine small molecule microarray and confocal laser scanning microscopy for the discovery of new fluorescent dyes among thousands of diverse compounds.

14585 different compounds were spotted in microarray format, and then fluorescent signals deriving from the molecules were detected by using a microarray scanner. In the course of data analysis 278 small molecules showing strong fluorescent emission were selected for microscopic live cell investigation. After filtering out compounds with impermeability, toxicity, low solubility or low in-cell fluorescence, 11 fluorescent dye candidates were further studied. Intracellular localization of the fluorochromes was determined by colocalization with known fluorescent markers: tested chemicals were localized to lipid droplets, mitochondria, plasma membrane and perinuclear/cytoplasmic region. All five of our lipid droplet-labelling molecules allow in vivo analysis of these organelles, unlike routinely used Oil Red O stain that requires cell fixation. B11 chemical localizes preferentially to plasma membrane and is still visible even after one day of incubation in culture without significant loss of cell viability, therefore this dye can also be used in long-term experiments. We have discovered an unusual spectral behavior of the $\mathrm{C} 2$ chemical. Repetitive laser-excitation caused relocalization of dye signal from mitochondria to cytoplasm/nucleolus.

The effect of the 11 molecules on long-term viability of cultured cells was assessed by using FDA-staining and testing for apoptotic nuclei formation. During a 24 hourstreatment none of the selected fluorochromes (except photoconverted C2) showed toxicity, hence these dyes are also suitable for long-term experiments.

We can conclude that combining the two approaches proved to be a suitable strategy in the discovery of novel, live cell staining fluorescent probes. 


\subsection{Affinity chromatographic application of small molecules immobilized on specific surfaces}

\subsubsection{Preparation and use in target identification of an affinity matrix based on AviLink surface modification technology}

Target validation is a critical step in drug development for understanding the mechanism of action and possible toxic effects of the candidate therapeutic agent. Affinity chromatography is a suitable technique for the determination of these target proteins: drug candidate immobilized on the resin fishes out interacting proteins from a mixture flowing through the resin.

Ligand immobilization on affinity resins has the same controversies (necessity of synthesis, improper orientation of the coupled molecule) like small molecule microarrays do, hence AviLink surface chemistry could be applied on the preparation of affinity matrices also. This novel type of resin was tested in the identification of interacting proteins of a newly synthesized trifluoro-amino-phtalimide derivative, Ac-2010.

Ac-2010 affinity matrix was prepared by using AviLink technology and loaded with total protein extract of rat liver. Bound proteins were eluted and analyzed on an SDSpolyacrylamide gel along with their parallel controls. Specific proteins binding the resin were identified by mass-spectrometry. Based on the chromatographic results, the intracellular localization and probable mechanism of action of the amino-trifluoro-phtalimide analogues, one of the 30 protein hits, PDI was selected to study whether Ac-2010 influence its enzymatic activity. In insulin turbidity assay Ac-2010 was found to be an inhibitor of the enzyme at a concentration as low as $1 \mu \mathrm{M}$ with an $\mathrm{IC}_{50}$ value of $3.158 \mu \mathrm{M}$.

Thus, PDI, as one of the possible interacting proteins identified by affinity chromatography, was shown not only binding to Ac-2010 molecule, but this interaction influences its enzymatic activity as well. Therefore we can conclude that AviLink technology enables us to prepare small molecule affinity resins, and these resins are applicable for the identification of small molecule-interacting proteins. 


\subsubsection{Removal of nonspecific binding proteins from cell and tissue extracts using 2-aminobenzimidazole-tethered affinity resin}

In complex biological samples the nonspecific binding of abundant proteins to small molecule-immobilized matrices makes the detection of low-abundance target proteins fairly challenging. Various approaches have been tried to overcome this problem: competitive elution, parallel application of active and inactive forms of the ligand, serial affinity chromatography, surface modifications, spacer induction or immunoaffinity-based depletion columns used in plasma proteomic studies.

We decided to prepare a depletion resin coupled with the small molecule 2aminobenzimidazole instead of specific antibodies, since benzimidazoles bind to the abundant cellular protein tubulin, which tends to stick non-specifically to affinity matrices. Reactive silanized CPG was synthesized for the basis of the resin, then isophtalic acid was built in as a spacer for the benzimidazole group. From the carbon content of each product resulted in the course of the preparation of the affinity resin we concluded that half of the active groups of the silanized CPG particles was successfully derivatized with 2aminobenzimidazole.

In order to evaluate the efficiency of the resin, it was used to deplete human A549 cell and rat brain total protein extracts, respectively. Proteins bounded by the resin were excised from gel following two-dimensional electrophoresis and identified by mass spectrometry (20 from A549 cell and 16 from brain sample): mainly cytoskeletal components (tubulins and actins), members of the 14-3-3 family and heat shock proteins were found. Some of the identified proteins are suspected to be co-entrapped with tubulin, other identified proteins are attached to the matrix via unrevealed interactions. In both depleted samples appearing of new proteins as well as an increase in the amount of some proteins were observed in the flow-through fraction, which are ascribed to the depletion of some nonspecific binders. Therefore we assume that application of the 2aminobenzimidazole resin on crude cell or tissue protein samples can facilitate the identification of intracellular drug targets. 


\section{Köszönetnyilvánítás}

Ezúton szeretnék köszönetet mondani mindazoknak, akik munkámat segítették. Elsősorban korábbi témavezetőmnek, Dr. Puskás Lászlónak, aki lehetővé tette, hogy a csoportjában dolgozzam, és ezalatt ellátott tanácsaival és új molekuláris biológiai módszerekbe vezetett be. Külön köszönöm neki, hogy doktorandusz éveim lejárta után is munkát adott nekem. Hálával gondolok Dr. Zvara Ágnesre, Dr. Fehér Liliánára, Dr. Fábián Gabriellára és Csapóné Török Rozáliára, akik egész munkám során támogattak tanácsaikkal, munkájukkal és barátságukkal. Köszönettel tartozom Dr. Ferhan Ayaydinnek, Lehőcz Istvánnénak, Juhász Juditnak, Dr. Hackler Lászlónak, Dr. Kanizsai Ivánnak, Gyuris Máriónak, Dr. Darula Zsuzsának, Dr. Hunyadi-Gulyás Évának és Klem Józsefnek a szakmai segítségért, valamint jelenlegi témavezetőmnek, Dr. Magyar Zoltánnak a dolgozat megírása alatt tanúsított türelméért.

Hálás vagyok szüleimnek és barátaimnak, akik mindvégig biztattak.

Szilárdnak köszönöm a támogatást, amellyel segített átvészelni a dolgozat megírásának időszakát. 


\section{Irodalomjegyzék}

1. Lipinski CA, Lombardo F, Dominy BW, Feeney PJ. Experimental and computational approaches to estimate solubility and permeability in drug discovery and development settings. Adv Drug Deliv Rev. 2001 Mar 1;46(1-3):3-26. Review.

2. Furka A, Bennett WD. Combinatorial libraries by portioning and mixing. Comb Chem High Throughput Screen. 1999 Apr;2(2):105-22. Review.

3. Fehérvári A. Patentability of inventions related to combinatorial chemistry. Ind Prop Copyr Rev. 2005 Dec;110(6)

4. Hackler L Jr, Dormán G, Kele Z, Urge L, Darvas F, Puskás LG. Development of chemically modified glass surfaces for nucleic acid, protein and small molecule microarrays. Mol Divers. 2003;7(1):25-36.

5. Darvas F, Dormán G, Krajcsi P, Puskás LG, Kovári Z, Lörincz Z, Urge L. Recent advances in chemical genomics. Curr Med Chem. 2004 Dec;11(23):3119-45. Review.

6. Molnár E, Hackler L, Jankovics T, Ürge L, Darvas F, Fehér LZ, Lőrincz Z, Dormán G, Puskás LG. Application of small molecule microarrays in comparative chemical proteomics. QSAR Comb Sci. 2006 Nov;25(11):1020-6.

7. Lam KS, Renil M. From combinatorial chemistry to chemical microarray. Curr Opin Chem Biol. 2002 Jun;6(3):353-8. Review.

8. Uttamchandani M, Lee WL, Wang J, Yao SQ. Quantitative inhibitor fingerprinting of metalloproteases using small molecule microarrays. J Am Chem Soc. 2007 Oct 31;129(43):13110-7.

9. Urbina HD, Debaene F, Jost B, Bole-Feysot C, Mason DE, Kuzmic P, Harris JL, Winssinger N. Self-assembled small-molecule microarrays for protease screening and profiling. Chembiochem. 2006 Nov;7(11):1790-7.

10. Lee HY, Park SB. Surface modification for small-molecule microarrays and its application to the discovery of a tyrosinase inhibitor. Mol Biosyst. 2011 Feb;7(2):304-10. 
11. Shi H, Liu K, Xu A, Yao SQ. Small molecule microarray-facilitated screening of affinity-based probes (AfBPs) for gamma-secretase. Chem Commun (Camb). 2009 Sep 7;(33):5030-2.

12. Koehler AN, Shamji AF, Schreiber SL. Discovery of an inhibitor of a transcription factor using small molecule microarrays and diversity-oriented synthesis. J Am Chem Soc. 2003 Jul $16 ; 125(28): 8420-1$.

13. Stanton BZ, Peng LF, Maloof N, Nakai K, Wang X, Duffner JL, Taveras KM, Hyman JM, Lee SW, Koehler AN, Chen JK, Fox JL, Mandinova A, Schreiber SL. A small molecule that binds Hedgehog and blocks its signaling in human cells. Nat Chem Biol. 2009 Mar;5(3):154-6.

14. Herschel Sir JFW. On a case of superficial colour presented by a homogeneous liquid internally colorless. Phil Trans Roy Soc London. 1845;135:143-5.

15. Stokes GG. On the change of refrangibility of light. Phil Trans Roy Soc London. 1852 Jan;142:463-562.

16. Baeyer A. Ueber eine neue Klasse von Farbstoffen. Ber Dtsch Chem Ges. 1871;4:555-8.

17. Ceresole M. Production of new red coloring matter. U.S. Patent 377,349. 1888.

18. Loudet A, Burgess K. BODIPY dyes and their derivatives: syntheses and spectroscopic properties. Chem Rev. 2007 Nov;107(11):4891-932.

19. Luo S, Zhang E, Su Y, Cheng T, Shi C. A review of NIR dyes in cancer targeting and imaging. Biomaterials. 2011 Oct;32(29):7127-38. Review.

20. Ellinger P. Fluorescence microscopy in biology. Biol Rev. 1940;15:323-47.

21. von Prowazek S. Über Fluorescenz der Zellen. Kleinwelt. 1914;6:37-40.

22. Coons AH, Creech HJ, Jones RN, Berliner E. The demonstration of pneumococcal antigen in tissues by the use of fluorescent antibody. J Immunol. 1942;45:159-70.

23. Shimomura O, Johnson FH, Saiga Y. Extraction, purification and properties of aequorin, a bioluminescent protein from the luminous hydromedusan, Aequorea. J Cell Comp Physiol. 1962 Jun;59:223-39. 
24. Prasher DC, Eckenrode VK, Ward WW, Prendergast FG, Cormier MJ. Primary structure of the Aequorea victoria green-fluorescent protein. Gene. 1992 Feb 15;111(2):229-33.

25. Chalfie M, Tu Y, Euskirchen G, Ward WW, Prasher DC. Green fluorescent protein as a marker for gene expression. Science. 1994 Feb 11;263(5148):802-5.

26. Inouye S, Tsuji FI. Aequorea green fluorescent protein. Expression of the gene and fluorescence characteristics of the recombinant protein. FEBS Lett. 1994 Mar 21;341(2-3):277-80.

27. Kapuscinski J. DAPI: a DNA-specific fluorescent probe. Biotech Histochem. 1995 Sep;70(5):220-33. Review.

28. Latt SA, Stetten G. Spectral studies on 33258 Hoechst and related bisbenzimidazole dyes useful for fluorescent detection of deoxyribonucleic acid synthesis. J Histochem Cytochem. 1976 Jan;24(1):24-33.

29. Tsien RY. Building and breeding molecules to spy on cells and tumors. FEBS Lett. 2005 Feb 7;579(4):927-32. Review.

30. Weissleder R, Pittet MJ. Imaging in the era of molecular oncology. Nature. 2008 Apr 3;452(7187):580-9. Review.

31. Chalfie M, Tu Y, Euskirchen G, Ward WW, Prasher DC. Green fluorescent protein as a marker for gene expression. Science. 1994 Feb 11;263(5148):802-5.

32. Crivat G, Taraska JW. Imaging proteins inside cells with fluorescent tags. Trends Biotechnol. 2012 Jan;30(1):8-16. Review.

33. Shaner NC, Patterson GH, Davidson MW. Advances in fluorescent protein technology. J Cell Sci. 2007 Dec 15;120(Pt 24):4247-60. Review.

34. Pollok BA, Heim R. Using GFP in FRET-based applications. Trends Cell Biol. 1999 Feb;9(2):57-60. Review.

35. Giepmans BN, Adams SR, Ellisman MH, Tsien RY. The fluorescent toolbox for assessing protein location and function. Science. 2006 Apr 14;312(5771):217-24. Review. 
36. Greenspan P, Mayer EP, Fowler SD. Nile red: a selective fluorescent stain for intracellular lipid droplets. J Cell Biol. 1985 Mar;100(3):965-73.

37. de Silva AP, Gunaratne HQ, Gunnlaugsson T, Huxley AJ, McCoy CP, Rademacher JT, Rice TE. Signaling Recognition Events with Fluorescent Sensors and Switches. Chem Rev. 1997 Aug 5;97(5):1515-1566.

38. Grynkiewicz G, Poenie M, Tsien RY. A new generation of Ca2+ indicators with greatly improved fluorescence properties. J Biol Chem. 1985 Mar 25;260(6):3440-50.

39. Minta A, Tsien RY. Fluorescent indicators for cytosolic sodium. J Biol Chem. 1989 Nov $15 ; 264(32): 19449-57$.

40. González JE, Tsien RY. Improved indicators of cell membrane potential that use fluorescence resonance energy transfer. Chem Biol. 1997 Apr;4(4):269-77.

41. Zaccolo M, De Giorgi F, Cho CY, Feng L, Knapp T, Negulescu PA, Taylor SS, Tsien RY, Pozzan T. A genetically encoded, fluorescent indicator for cyclic AMP in living cells. Nat Cell Biol. 2000 Jan;2(1):25-9.

42. Henrich S, Salo-Ahen OM, Huang B, Rippmann FF, Cruciani G, Wade RC. Computational approaches to identifying and characterizing protein binding sites for ligand design. J Mol Recognit. 2010 Mar-Apr;23(2):209-19.

43. Manning HC, Lander A, McKinley E, Mutic NJ. Accelerating the development of novel molecular imaging probes: a role for high-throughput screening. J Nucl Med. 2008 Sep;49(9):1401-4.

44. Li Q, Lee JS, Ha C, Park CB, Yang G, Gan WB, Chang YT. Solid-phase synthesis of styryl dyes and their application as amyloid sensors. Angew Chem Int Ed Engl. 2004 Nov 26;43(46):6331-5.

45. Simeonov A, Jadhav A, Thomas CJ, Wang Y, Huang R, Southall NT, Shinn P, Smith J, Austin CP, Auld DS, Inglese J. Fluorescence spectroscopic profiling of compound libraries. J Med Chem. 2008 Apr 24;51(8):2363-71.

46. Lea WA, Simeonov A. Fluorescence polarization assays in small molecule screening. Expert Opin Drug Discov. 2011 Jan;6(1):17-32. 
47. Yun SW, Leong C, Zhai D, Tan YL, Lim L, Bi X, Lee JJ, Kim HJ, Kang NY, Ng SH, Stanton LW, Chang YT. Neural stem cell specific fluorescent chemical probe binding to FABP7. Proc Natl Acad Sci U S A. 2012 Jun 26;109(26):10214-7.

48. Li Q, Kim Y, Namm J, Kulkarni A, Rosania GR, Ahn YH, Chang YT. RNA-selective, live cell imaging probes for studying nuclear structure and function. Chem Biol. 2006 Jun;13(6):615-23.

49. Halbhuber KJ, König K. Modern laser scanning microscopy in biology, biotechnology and medicine. Ann Anat. 2003 Jan;185(1):1-20. Review.

50. Oheim M. Advances and challenges in high-throughput microscopy for live-cell subcellular imaging. Expert Opin Drug Discov. 2011 Dec;6(12):1299-315.

51. Raida M. Drug target deconvolution by chemical proteomics. Curr Opin Chem Biol. 2011 Aug;15(4):570-5. doi: 10.1016/j.cbpa.2011.06.016. Epub 2011 Jul 18. Review.

52. Harding MW, Galat A, Uehling DE, Schreiber SL. A receptor for the immunosuppressant FK506 is a cis-trans peptidyl-prolyl isomerase. Nature. 1989 Oct 26;341(6244):758-60.

53. Taunton J, Hassig CA, Schreiber SL. A mammalian histone deacetylase related to the yeast transcriptional regulator Rpd3p. Science. 1996 Apr 19;272(5260):408-11.

54. Fukuda M, Asano S, Nakamura T, Adachi M, Yoshida M, Yanagida M, Nishida E. CRM1 is responsible for intracellular transport mediated by the nuclear export signal. Nature. 1997 Nov 20;390(6657):308-11.

55. Kosaka T, Okuyama R, Sun W, Ogata T, Harada J, Araki K, Izumi M, Yoshida T, Okuno A, Fujiwara T, Ohsumi J, Ichikawa K. Identification of molecular target of AMP-activated protein kinase activator by affinity purification and mass spectrometry. Anal Chem. 2005 Apr 1;77(7):20505 .

56. Yamamoto K, Yamazaki A, Takeuchi M, Tanaka A. A versatile method of identifying specific binding proteins on affinity resins. Anal Biochem. 2006 May 1;352(1):15-23.

57. von Rechenberg M, Blake BK, Ho YS, Zhen Y, Chepanoske CL, Richardson BE, Xu N, Kery V. Ampicillin/penicillin-binding protein interactions as a model drug-target system to optimize affinity pull-down and mass spectrometric strategies for target and pathway identification. Proteomics. 2005 May;5(7):1764-73. 
58. Shimizu N, Sugimoto K, Tang J, Nishi T, Sato I, Hiramoto M, Aizawa S, Hatakeyama M, Ohba R, Hatori H, Yoshikawa T, Suzuki F, Oomori A, Tanaka H, Kawaguchi H, Watanabe H, Handa H. High-performance affinity beads for identifying drug receptors. Nat Biotechnol. 2000 Aug;18(8):87781.

59. Tamura T, Terada T, Tanaka A. A quantitative analysis and chemical approach for the reduction of nonspecific binding proteins on affinity resins. Bioconjug Chem. 2003 Nov-Dec;14(6):1222-30.

60. Bandow JE. Comparison of protein enrichment strategies for proteome analysis of plasma. Proteomics. 2010 Apr;10(7):1416-25.

61. Chromy BA, Gonzales AD, Perkins J, Choi MW, Corzett MH, Chang BC, Corzett CH, McCutchen-Maloney SL. Proteomic analysis of human serum by two-dimensional differential gel electrophoresis after depletion of high-abundant proteins. J Proteome Res. 2004 Nov-Dec;3(6):11207.

62. Szafranski C, Bailey J, Turck CW, Nicol G, Martosella J, Zolotarjova N. Enhancing analytical access to low-abundant proteins in the human plasma proteome. PharmaGenomics. 2004 Sep 1;40-6.

63. Lacey E. The role of the cytoskeletal protein, tubulin, in the mode of action and mechanism of drug resistance to benzimidazoles. Int J Parasitol. 1988 Nov;18(7):885-936. Review.

64. Friedman PA, Platzer EG. Interaction of anthelmintic benzimidazoles and benzimidazole derivatives with bovine brain tubulin. Biochim Biophys Acta. 1978 Dec 18;544(3):605-14.

65. Lundström J, Holmgren A. Protein disulfide-isomerase is a substrate for thioredoxin reductase and has thioredoxin-like activity. J Biol Chem. 1990 Jun 5;265(16):9114-20.

66. Sandoval JE. Equation for calculating surface coverage from end-capping of chromatographic bonded phases. J Chromatogr A. 1999 Aug 13;852(2):375-81.

67. Haugland RP, Spence MTZ, Johnson ID, Basey A. The Handbook: A Guide to Fluorescent Probes and Labeling Technologies, 10th ed. Molecular Probes: Eugene, OR, USA. 2005

68. Puskás LG, Fehér LZ, Vizler C, Ayaydin F, Rásó E, Molnár E, Magyary I, Kanizsai I, Gyuris M, Madácsi R, Fábián G, Farkas K, Hegyi P, Baska F, Ozsvári B, Kitajka K. Polyunsaturated fatty acids synergize with lipid droplet binding thalidomide analogs to induce oxidative stress in cancer cells. Lipids Health Dis. 2010 Jun 2;9:56. 
69. Alvarez M, Villanueva A, Acedo P, Cañete M, Stockert JC. Cell death causes relocalization of photosensitizing fluorescent probes. Acta Histochem. 2011 May;113(3):363-8.

70. Johnson VL, Ko SC, Holmstrom TH, Eriksson JE, Chow SC. Effector caspases are dispensable for the early nuclear morphological changes during chemical-induced apoptosis. J Cell Sci. 2000 Sep;113 ( Pt 17):2941-53.

71. Feige MJ, Hendershot LM. Disulfide bonds in ER protein folding and homeostasis. Curr Opin Cell Biol. 2011 Apr;23(2):167-75. Review.

72. Ghosal D, Shappell NW, Keenan TW. Endoplasmic reticulum lumenal proteins of rat mammary gland. Potential involvement in lipid droplet assembly during lactation. Biochim Biophys Acta. 1994 Jul 6;1200(2):175-81.

73. Sánchez C, Padilla R, Paciucci R, Zabala JC, Avila J. Binding of heat-shock protein 70 (hsp70) to tubulin. Arch Biochem Biophys. 1994 May 1;310(2):428-32.

74. Gache V, Louwagie M, Garin J, Caudron N, Lafanechere L, Valiron O. Identification of proteins binding the native tubulin dimer. Biochem Biophys Res Commun. 2005 Feb 4;327(1):35-42.

75. Garnier C, Barbier P, Gilli R, Lopez C, Peyrot V, Briand C. Heat-shock protein 90 (hsp90) binds in vitro to tubulin dimer and inhibits microtubule formation. Biochem Biophys Res Commun. 1998 Sep 18;250(2):414-9.

76. Kumagai H, Sakai H. A porcine brain protein ( $35 \mathrm{~K}$ protein) which bundles microtubules and its identification as glyceraldehyde 3-phosphate dehydrogenase. J Biochem. 1983 May;93(5):1259-69.

77. Pozuelo Rubio M, Geraghty KM, Wong BH, Wood NT, Campbell DG, Morrice N, Mackintosh C. 14-3-3-affinity purification of over 200 human phosphoproteins reveals new links to regulation of cellular metabolism, proliferation and trafficking. Biochem J. 2004 Apr 15;379(Pt 2):395-408.

78. Dave RH, Saengsawang W, Yu JZ, Donati R, Rasenick MM. Heterotrimeric G-proteins interact directly with cytoskeletal components to modify microtubule-dependent cellular processes. Neurosignals. 2009;17(1):100-8. Review. 


\section{Publikációk jegyzéke}

*Az értekezéshez közvetlenül kapcsolódó közlemények.

Referált folyóiratokban megjelent cikkek:

1. Molnár E, Hackler L, Jankovics T, Ürge L, Darvas F, Fehér LZ, Lőrincz Z, Dormán G, Puskás LG. Application of small molecule microarrays in comparative chemical proteomics. QSAR Comb Sci. 2006 Nov;25(11):1020-6.

2. Ménesi D, Kitajka K, Molnár E, Kis Z, Belleger J, Narce M, Kang JX, Puskás LG, Das UN. Gene and protein expression profiling of the fat-1 mouse brain. Prostaglandins Leukot Essent Fatty Acids. 2009 Jan;80(1):33-42.

3. Puskás LG, Fehér LZ, Vizler C, Ayaydin F, Rásó E, Molnár E, Magyary I, Kanizsai I, Gyuris M, Madácsi R, Fábián G, Farkas K, Hegyi P, Baska F, Ozsvári B, Kitajka K. Polyunsaturated fatty acids synergize with lipid droplet binding thalidomide analogs to induce oxidative stress in cancer cells. Lipids Health Dis. 2010 Jun 2;9:56.

*4. Molnár E, Fábián G, Klem J, Darula Z, Hunyadi-Gulyás E, Medgyesi A, Medzihradszky KF, Puskás LG. Removal of nonspecific binding proteins from cell and tissue extracts using 2-aminobenzimidazole-tethered affinity resin. Pharmazie. 2011 Sep;66(9):662-5.

*5. Molnár E, Kuntam S, Cingaram PKR, Peksel B, Suresh B, Fábián G, Fehér LZ, Bokros A, Medgyesi Á, Ayaydin F, Puskás LG. Combination of small molecule microarray and confocal microscopy techniques for live cell staining fluorescent dye discovery. Molecules. (beküldve 2013-ban, megosztott első szerzö)

*6. Nagy LI, Molnár E, Kanizsai I, Ózsvári B, Fehér LZ, Fábián G, Marton A, Vizler C, Ayaydin F, Kitajka K, Hackler L, Mátés L, Deák F, Kiss I, Puskás LG. Lipid droplet binding thalidomide analogs activate endoplasmic reticulum stress and suppress hepatocellular carcinoma in a chemically induced transgenic mouse model. Curr Pharm Design. (beküldve 2013-ban) 


\section{Szabadalmak:}

*1. Bejelentés címe: Aktív hordozó, eljárás az aktív hordozó előállítására és az aktív hordozó alkalmazása. Ügyiratszám: P0600668 Bejelentés dátuma: 2006.08.22.

2. Bejelentés címe: Lipidcseppecskék jelzésére szolgáló vegyületek, lipidcseppecskék jelzésére szolgáló kompozíciók, valamint eljárás sejtek és/vagy sejtalkotók megjelenítésére. Ügyiratszám: P0700432 Bejelentés dátuma: 2007.06.21.

3. Bejelentés címe: Celluláris vezikuláris rendszerek, különösen lipidcseppecskék kialakulását és/vagy müködését befolyásoló vegyületek, az ilyen vegyületeket tartalmazó gyógyászati kompozíciók, valamint ilyen vegyületek alkalmazása betegségállapotok kezelésére. Ügyiratszám: P0700433 Bejelentés dátuma: 2007.06.21.

*4. Bejelentés címe: Fehérjék tisztítására szolgáló új affinitás-felület, ennek előállítása és alkalmazása. Ügyiratszám: P1000515 Bejelentés dátuma: 2010.09.23. 